\title{
CABILDOS DE CLÉRIGOS EN LA BAJA EDAD MEDIA. LOS CASOS DE ALCARAZ (ALBACETE) Y TRESJUNCOS (CUENCA)
}

\author{
POR \\ CARLOS AYLLÓN GUTIÉRREZ \\ Instituto de Estudios Albacetenses Don Juan Manuel
}

\section{RESUMEN}

Durante la Edad Media aparecieron en toda la cristiandad numerosas cofradías. Entre ellas tuvieron una especial relevancia las compuestas por clérigos seculares, que pretendieron influir sobre la sociedad local. Para ella celebraban oficios religiosos funerarios y a cambio captaban numerosas rentas que se añadían a los beneficios parroquiales de los clérigos. En este estudio se propone un acercamiento a dos cofradías de clérigos creadas en el sureste de Castilla durante la baja Edad Media: los cabildos de Alcaraz y Tresjuncos.

\section{PALABRAS CLAVE}

Baja Edad Media; clero secular; cofradías; sureste de Castilla; rentas agrarias; sociedad medieval.

\section{CONFRATERNITIES OF PRIESTS IN THE LATER MIDDLE AGES. THE EXAMPLES OF ALCARAZ (ALBACETE) AND TRESJUNCOS (CUENCA)}

\section{ABSTRACT}

During the Middle Ages numerous confraternities appeared in Christendom. Among those the ones being composed by secular clergymen had a special relevance, as they tried to influence the local 
society, to which funeral ceremonies were held. In exchange they used to get many revenues added to their parish benefits. This study proposes an approach to two fraternities of priests created in the south-east of Castile during the late Middle Ages: the brotherhoods of Alcaraz and Tresjuncos.

\section{KEY WORDS}

Late Middle Ages; secular clergy; confraternities; south-east of Castile; rural incomes; medieval society.

$\begin{array}{ll}\text { Recibido/Received } & 31-01-2012 \\ \text { Aceptado/Accepted } & 26-04-2014\end{array}$

A partir del siglo XII se generaliza la tendencia de los clérigos seculares a constituir cofradías — también denominadas cabildos, hermandades, abadías o universidades - que presentaban unos rasgos semejantes a los que caracterizaron a las constituidas por corporaciones profesionales de laicos. Este fenómeno, desarrollado con especial intensidad durante la baja Edad Media, se ha venido estudiando con cierta profusión en las últimas décadas al calor del auge de los trabajos sobre religiosidad popular como parcela significativa de la Historia de la Iglesia. No obstante, y pese a la abundancia de títulos, todavía quedan muchas dudas por despejar y también faltan obras de síntesis que recapitulen tales estudios, que con toda evidencia adolecen hasta la fecha de dispersión y desequilibrio geográficos. Más difícil es hallar siquiera un breve trabajo que acometa el fenómeno de las hermandades de clérigos, que de momento sólo aparecen someramente apuntadas en estudios de índole tangencial. Por añadidura, la escasez de fuentes conservadas con respecto a estas corporaciones ayuda a explicar tal carencia historiográfica. ${ }^{1}$

${ }^{1}$ Martín Rodríguez, J. L. 1993. "Hermandades y ligas de clérigos en los reinos hispánicos". Cofradías, gremios y solidaridades en la Europa Medieval. XIX Semana de Estudios Medievales de Estella: 127-147. Breve pero atinada incursión general en el fenómeno, Martín Martín, J. L. 2003: "El clero rural en la Corona de Castilla", en $\mathrm{M}^{\mathrm{a}}$ Desamparados Martínez San Pedro y Dolores Segura del Pino (ed.), La Iglesia en el mundo medieval y moderno: 71 y ss. Almería: Instituto de Estudios Almerienses. Otros trabajos acerca de estos cabildos de clérigos: Diago Hernando, M. 1997. "El cabildo de clérigos de Ágreda a comienzos de la Edad Moderna", Celtiberia 91: 43-68. Osorio Muñoz, M. 1984. "El bajo clero en Jaén en el tránsito a la Edad Moderna. La universidad de curas párrocos", La sociedad medieval andaluza: grupos no privilegiados (Actas del III Coloquio de Historia Medieval de Andalucía): 457- 
Como las demás cofradías, las de clérigos se conciben como asociaciones de fieles hermanados con fines benéfico-asistenciales o religiosos, aunque ambos objetivos suelen aparecer asociados. Pretendían garantizar la atención de sus propios componentes necesitados tanto en situación de enfermedad como de fallecimiento, en cuyo caso el grupo se encargaría de oficiar las oportunas exequias. En circunstancias menos dramáticas buscaban el fomento de ciertas actividades litúrgicas y la defensa de unos intereses comunes, lo que además podía hacerse compatible con la promoción de actos caritativos. No obstante, llama la atención la escasez de acciones benéficas por parte de estas cofradías, así como de las demás entidades integradas en la Iglesia bajomedieval. En este sentido, aunque el mensaje de misericordia esté presente como leit motiv en el discurso eclesial, no es menos cierto que la caridad tendió a ir encaminada a beneficiar al propio clero y rara vez a los más necesitados. De hecho la clerecía, más que practicar la limosna, se dirigía a la sociedad civil para que fueran sus componentes quienes facilitasen la acción benéfica. De este modo cabildos, parroquias y conventos se convierten en simples medios que instrumentalizan la desigualdad al objeto de cumplir cierto plan divino en provecho propio.

Asimismo, los clérigos se asociaron en algunas poblaciones con el objeto de preservar sus privilegios e intereses frente a injerencias externas, y así, entre finales del siglo XIII y principios del XIV estas cofradías adquirieron cierto auge para defenderse frente a la pujanza del poder nobiliario. ${ }^{2}$ A estas razones, Cathérine Vincent añade que las cofradías de clérigos surgieron en ocasiones por el afán de dotar de cierta dignidad a los clérigos en activo, muchos de ellos pobres, pues la constitución del grupo les permitía adquirir más bienes y gestionarlos con mayor facilidad. ${ }^{3}$

El hecho de que los integrantes de estas cofradías poseyeran en común el ejercicio de la clerecía confería a tales cabildos una naturaleza bien diferenciada. Sus ceremonias se proyectaban hacia otros miembros de la sociedad, encargándose de organizar -entre otros rituales solemnes - las exequias fúnebres y los aniversarios por el alma de los diferentes convecinos que se las encargaban, movidos por el hecho de

468; Herrera Mesa, P. 1978. "La universidad de clérigos de Córdoba en la baja Edad Media", Actas del I Congreso de Historia de Andalucía. Andalucía Medieval, II: 133-145.

2 Martín Rodríguez, J. L. 1993: 135-136.

${ }^{3}$ Vincent, C. 1993. "Les confréries de bas clercs, un expédient pour la réforme des séculiers? L'exemple du Mans", Le clerc séculier au Moyen Âge: 273. Paris: Editions de La Sorbonne. 
que el ceremonial oficiado por los cofrades clérigos aseguraba un mayor aparato que las misas de difuntos concertadas en las parroquias. En consecuencia, los donantes cedían sus bienes al cabildo a fondo perdido, desviando en provecho de los componentes del cabildo diversas rentas e impidiendo que éstas revirtieran en el resto del clero parroquial.

Dentro de la organización institucional de la Iglesia, las hermandades de eclesiásticos gozaron de una notable autonomía: sometidas a la autoridad de un superior o abad - cargo que se renovaba cada año-, sus actividades no se hallaban sujetas al régimen parroquial, lo que las mantenía apartadas del entramado diocesano. Asimismo, quedaban al margen de la piedad popular —en la que se suele encuadrar el fenómeno de las cofradías-, dado que la naturaleza clerical de sus integrantes canalizaba sus manifestaciones litúrgicas hacia una religiosidad ortodoxa y - digamos-culta.

Durante el bajo Medievo la geografía castellana se vio salpicada de multitud de estas hermandades, originadas en algunas poblaciones al hilo de la conquista cristiana, pese a lo cual resulta exagerado afirmar que existieron cabildos de clérigos prácticamente en todos los concejos de Castilla. ${ }^{4}$ Tras crearse muchas de estas cofradías en la mitad septentrional de la Península (Guadalajara, Ávila, Salamanca...), a partir del siglo XIII comenzaron a aparecer en la meseta sur. En Toledo y en Talavera se constituyeron sendas corporaciones similares que establecieron cierta asociación entre sí en 1258 frente a las intromisiones de los arzobispos. De poco sirvió que ese mismo año Alfonso $X$ reiterara la prohibición de crear cofradías que no estuviesen orientadas a objetivos estrictamente piadosos y benéficos, aunque precisamente para ajustarse a estas disposiciones reales en Sevilla, Jerez, Carmona y Jaén también se instituyeron universidades de clérigos parroquiales de ámbito local que, organizadas bajo la advocación de un santo patrón cuya festividad celebraban los integrantes, atendían enfermos y difuntos. ${ }^{5}$

Los cabildos que acogían clérigos presentaban cierta variedad en cuanto a su composición. Así, con diversos grados de elitismo o hermetismo los podemos encontrar exclusivamente compuestos por beneficiados parroquiales (Huete, Arjona), otros sólo de capellanes (Huete, Cuenca), los que englobaban a ambas categorías (Alcaraz, Alcocer), restringidos a presbíteros y diáconos (Paredes de Nava) o mixtos compuestos de clérigos y laicos (Astorga, Cellorigo, Fongriega), que en algunos casos llegan a admitir mujeres (Béjar). También se diferencian los que se componían de clérigos de una sola población -

${ }^{4}$ Martín Rodríguez, J. L. 1993: 143.

${ }^{5}$ Sánchez Herrero, J. 1990. "La Iglesia y la religiosidad andaluza durante los siglos XIII al XV", XX siglos 3-4: 450. 
que fueron la gran mayoría- de los que abarcaban varios núcleos próximos entre sí (tierra de Béjar, comarca de Arévalo, tierra de Plasencia, Moya, común de Uclés, el ya citado de Tresjuncos...). ${ }^{6}$

Algunos cabildos surgieron por iniciativa episcopal y en tal caso eran los obispos quienes otorgaban las ordenanzas para su régimen. Otras cofradías, en cambio, se crearon por propia decisión de sus componentes, quienes con frecuencia se otorgaban a sí mismos su propio reglamento que entendemos estaría sujeto a la supervisión de las autoridades diocesanas. En todo caso, los estatutos eran susceptibles de modificaciones.

Aunque muchos cabildos nacieron y continuaron como sencillas cofradías de eclesiásticos sin grandes pretensiones, algunos de ellos acabaron constituyendo entidades de gran peso social y económico en su comarca. No en vano gozaron de consideración por parte de sus convecinos, lo que se tradujo en la disposición de los pobladores en otorgarles donaciones a cambio de vigilias y aniversarios. De este modo algunas hermandades llegaron a atesorar, como veremos, grandes volúmenes de rentas y bienes, lo que desmiente la tesis que afirma que los cabildos rurales de beneficiados no llegaron a atesorar un amplio patrimonio mediante la recepción de donaciones. ${ }^{7}$

Las páginas sucesivas pretenden ampliar el conocimiento actual de este tipo de cofradías a través del análisis de dos de ellas, las que florecieron durante la baja Edad Media en el núcleo de Alcaraz y en la comarca conquense de Tresjuncos. El hecho de escogerlas estriba en que ambas se encuentran emplazadas en un área geográfica, el sureste de la Meseta castellana, que permanecía sin arrojar ningún estudio mínimamente detenido sobre este fenómeno. No obstante, la zona también vio surgir otros cabildos locales de clérigos o al menos con eclesiásticos entre sus componentes. En Chinchilla (diócesis de Cartagena), a principios del siglo XVI, el poderoso clérigo Gil Sánchez Soriano, junto a Francisco de Salas y otros eclesiásticos creó la cofradía de San Ildefonso, que parece proceder de otra, llamada del Cuerpo de Dios, creada poco antes de 1470, aunque ésta parece que fuera de carácter mixto con clérigos y seglares. ${ }^{8}$

${ }^{6}$ Martín Martín, J. L. 2003: 72-73; Díaz lbáñez, J. 2003. Iglesia, sociedad y poder en Castilla. El obispado de Cuenca en la Edad Media, 232-234. Cuenca: Alfonsípolis.

${ }^{7}$ Martín Martín, J. L. 2003: 73.

${ }^{8}$ Marsilla de Pascual, F. 1989. "Aportación al estudio de las cofradías religiosas en la diócesis de Cartagena. Siglo XV", Mayurqa 22: 384. Cabe sospechar que la cofradía del Cuerpo de Dios se transformó en la de San Ildefonso dada la pertenencia a ambas de miembros de la familia Salas. 
Dentro de la diócesis conquense, en las ciudades de Cuenca y Huete surgieron cabildos de eclesiásticos parroquiales al poco tiempo de que ambas plazas fuesen conquistadas por las tropas castellanas. A ellos hay que añadir otras cofradías análogas en poblaciones más pequeñas (Moya, Uclés, Alcocer). Asimismo, en el arcedianazgo de Alarcón (coincidente con la Mancha conquense) se constituyeron con distinto grado de fortuna algunas hermandades de clérigos. En Castillo de Garcimuñoz se creó la integrada por los beneficiados y capellanes perpetuos de la iglesia parroquial de San Juan Bautista. ${ }^{9}$ La lejanía de Garcimuñoz con respecto a la sede episcopal y acaso un firme apoyo de los señores de Villena a la iglesia local debieron de influir en la institución de esta cofradía. La primera noticia sobre ella la tenemos de mediados del siglo XV, cuando la componían apenas media docena de clérigos. ${ }^{10}$ Entre ellos sobresale la figura de Pedro Martínez de Toledo, titular de la capilla real del alcázar como heredero del oficio que había instituido don Juan Manuel a principios del siglo XIV cuando fue señor de Villena. Precisamente en 1456 este capellán arrendó todos los diezmos de las propiedades del colectivo. Sobre esta renta, en 1527 se señala que el cabildo "tiene por costumbre muy antigua hasta el dia de oy de llebar los diezmos de sus posesiones, viñas y haças y guertas assi de las que tiene arrendadas como de las que tiene asensadas". ${ }^{11}$

Bien distinto es lo ocurrido en Alarcón, villa en la que se fundó otro cabildo de beneficiados, que acabaría en un proyecto, si no frustrado, al menos de escaso éxito ${ }^{12}$. Los paralelismos existentes entre las villas de Alarcón y Alcaraz en cuanto a su organización primigenia, hacen altamente probable que en la primera se instituyera durante la conquista una hermandad de clérigos similar a la alcaraceña, aunque el cabildo catedralicio de Cuenca - principal interesado en que las rentas eclesiásticas de la zona no fueran a parar a otras entidades religiosasejercería presión para abortar cualquier intento de consolidación de una hermandad clerical en Alarcón.

${ }^{9}$ Díaz lbáñez, J. 2003: 235.

${ }^{10}$ En 1457 el prior es Juan Fernández Mexeda, y los capellanes Pedro Martínez de Toledo, Juan Fernández de La Parrilla, Juan Rodríguez, Sancho García y Juan López Bermejo. Todos continúan cinco años después, aunque el último se hace llamar entonces Juan López de Tigos. Archivo Diocesano de Cuenca: Parroquias, libro 98, f. 31r.

${ }^{11}$ Idem; Ayllón Gutiérrez, C. 2010. "Las iniciativas religiosas de don Juan Manuel en el señorío de Villena", Homenaje al profesor Eloy Benito Ruano: 110. Murcia: Sociedad Española de Estudios Medievales.

12 En 1398 hay constancia de algunos inmuebles de este cabildo. Lasso de la Vega, M. 1945. El Señorío de Valverde: 31. Cuenca. 
Pero en todo el arcedianazgo fue mucho más sólido el cabildo de Tresjuncos, compuesto por beneficiados de pueblos próximos a esta aldea $^{13}$ y que, por su volumen de rentas, su capacidad de influencia social y su perdurabilidad, sólo parece comparable en el cuadrante sureste peninsular al de Alcaraz.

\section{EL CABILDO LOCAL DE ALCARAZ}

Nada más conquistarse Alcaraz (1213) se constituyó a iniciativa del arzobispo don Rodrigo Jiménez de Rada una corporación local de clérigos - siempre denominada cabildo-, entre cuyos objetivos estuvo disponer los más importantes actos litúrgicos de la villa (exequias solemnes, procesiones o misas con motivo de alguna fecha señalada). Su creación, al parecer confirmada por Inocencio III, pretendía asegurar la presencia de un clero operativo en un área sometida a los peligros fronterizos. Así pues, el cabildo de curas, beneficiados y capellanes de Alcaraz —que a diferencia de la mayoría de cofradías de clérigos no quedó bajo la advocación de ningún santo titular- nació como incentivo para atraer clérigos de otras latitudes a la recién conquistada villa, pero también para velar por los intereses del clero local activo salvaguardándolo frente a intromisiones ajenas.

La pertenencia a la hermandad se retribuía con ciertas raciones o partes iguales aparte de los beneficios parroquiales con que se remuneraba separadamente a cada uno de los clérigos. Pero para poder ingresar en la cofradía y por ende recibir las correspondientes gratificaciones era condición sine qua non residir en Alcaraz, por lo que cada clérigo debería atender su correspondiente parroquia y asistir a las celebraciones diarias en las horas canónicas. Esta exigencia hizo que no todos los clérigos de la población pudiesen pertenecer a la corporación, lo que la convertía en un exiguo colectivo de élite dentro de un grupo ya de por sí privilegiado y minoritario.

Es muy probable es que el propio arzobispo toledano fuera quien otorgase las ordenanzas para su régimen. El cabildo inicialmente se componía de cuatro curas, tantos como parroquias instituidas (ampliadas a cinco en el siglo XIV), y a ellos se fueron añadiendo algunos beneficiados simples o servideros de dichas iglesias a medida que sus oficios se fueron instituyendo. ${ }^{14}$ Después, a partir de cierto momento

13 Díaz lbáñez, J. 2003: 226-235. En Plasencia existió otra cofradía de clérigos que abarcaba varias aldeas además del núcleo principal placentino (Martín Martín, J. L. 2003: 71, nota 49).

14 Ayllón Gutiérrez, C. 2013. "El arcedianazgo de Alcaraz en sus orígenes" en Alcaraz. Del Islam al concejo castellano: 160-162. Albacete: Instituto de Estudios Albacetenses-Ayuntamiento de Alcaraz. 
también se fueron incorporando capellanes con oficio en las capellanías de alguna de las citadas parroquias de la ciudad.

Los clérigos capitulares de Alcaraz asumían el compromiso impuesto desde los tiempos de Jiménez de Rada- de ir "los viernes en la tarde despues de bisperas a cantar e desir vna vegilia de tres liçiones por los reyes e arçobispos e por los bienfechores del dicho cabildo". ${ }^{15}$ Ello apunta a que tanto el rey como el arzobispo tuvieron un protagonismo directo en la creación del cabildo, puesto que en otros lugares los cofrades normalmente sólo ruegan por ellos mismos y por sus donantes. Al día siguiente completaban su obligación rezando una misa dedicada a Santa María. Tales ceremonias se realizaban con carácter rotatorio por las distintas iglesias de la población, de un modo semejante a como hacía la hermandad clerical de Córdoba. ${ }^{16}$

\section{Los componentes del cabildo}

En Alcaraz se denominaba abad al miembro del cabildo local de clérigos que ejercía de director. Era el encargado de velar por el cumplimiento de las ordenanzas capitulares y a él atañía la iniciativa para redactar las disposiciones que convinieran para el mejor funcionamiento del organismo; también se ocupaba de gestionar los bienes, ingresos y gastos, siendo quien abonaba las correspondientes raciones a los compañeros, debido a lo cual el cabildo prescindió de la intervención de un mayordomo, lo que reforzaba el carácter cerrado del cabildo con respecto a la sociedad civil. Por todas estas funciones el abad percibía unos derechos adicionales llamados de preste y abadía.

El abad —que, cuando se ausentaba, dejaba en su lugar a un teniente de abad- era elegido entre los componentes del cabildo,

15 Archivo Diocesano de Albacete (en lo sucesivo "ADA"), ALZ (Alcaraz) 149 , f. 75 r. Básicamente la información recogida sobre este cabildo procede de este valioso libro intitulado: "Libro de çensales e vigillas e algunas constituçiones del cabildo", que abarca de 1498 a 1536.

${ }^{16}$ Se comenzaba en la iglesia de Santa María, para continuar después en la de San Ignacio y proseguir sucesivamente en las de San Miguel, la Trinidad y San Pedro. ADA, ALZ 149, f. 75r-v (acta de 30-enero-1507). Según las condiciones impuestas por Alfonso $X$ a la universidad de clérigos de San Eustaquio de Córdoba, quienes debían celebrar en la capilla "las fiestas solemnes de Santa María con diácono y subdiácono (...). En ella oficiarían también los días de San Eustaquio y de San Ildefonso, onomástica de Alfonso $X$, para rogar a Dios por la salud del rey, de la reina doña Violante y de sus hijos. Todos los primeros sábados de mes celebrarían una misa (...) en honor de Santa María (...)". Nieto Cumplido, M. 1991. Historia de la Iglesia en Córdoba. Reconquista y Restauración (1146-1326): 250-251. Córdoba: Cajasur. 
aunque no sabemos si el cargo se sorteaba o si se designaba por votación entre los capitulares, lo que parece más probable. En cualquier caso, no se procedía a la rotación, a la vista de las repeticiones en el cargo en que algunos cofrades incurrieron en un breve plazo de tiempo (CUADRO 1). La elección del cargo se efectuaba en torno al emblemático día de san Miguel, que es cuando el abad rendía cuentas de la gestión económica anual del cabildo, y su periodo de mandato era anual, con la posibilidad extraordinaria de verse prorrogado para el año siguiente. ${ }^{17}$

El incumplimiento de sus obligaciones acarreaba al superior sanciones perfectamente tipificadas en las ordenanzas internas. Por ejemplo, podía producirse el caso de que no desembolsase los derechos pecuniarios a los compañeros del cabildo, en cuyo caso estaba obligado a pagar como sanción el doble de lo que les debía haber entregado.

CUADRO 1

ABADES DEL CABILDO LOCAL DE ALCARAZ (1497-1518)

\begin{tabular}{|c|l|l|}
\hline AÑO & \multicolumn{1}{|c|}{ ABAD } & \multicolumn{1}{|c|}{ OFICIO PARROQUIAL } \\
\hline $1497-1498$ & Francisco de Morales & Cura de la Trinidad \\
\hline $1498-1499$ & García de Grajal & Cura de San Ignacio \\
\hline $1499-1500$ & Lope Rodríguez & Cura de San Pedro \\
\hline $1500-1501$ & Juan Sánchez de Montiel & Beneficiado en San Ignacio \\
\hline $1501-1502$ & Fernando Gómez & Beneficiado en San Pedro \\
\hline $1502-1503$ & Agustín de Beteta & Beneficiado en Santa María \\
\hline $1503-1504$ & Agustín de Beteta & Beneficiado en Santa María \\
\hline $1504-1505$ & \multicolumn{2}{|c|}{ (sin datos) } \\
\hline $1505-1506$ & García de Grajal & Cura de San Ignacio \\
\hline $1506-1507$ & Agustín de Beteta & Beneficiado en Santa María \\
\hline $1507-1508$ & Fernando Gómez & Beneficiado en San Pedro \\
\hline $1508-1509$ & Agustín de Beteta & Beneficiado en Santa María \\
\hline $1509-1510$ & Alfonso Rodríguez de Estrada & Cura de la Trinidad \\
\hline $1510-1511$ & Martín Alonso de Toledo & Beneficiado en San Ignacio \\
\hline $1511-1512$ & Juan Ramírez & Cura de Santa María \\
\hline $1512-1513$ & Alfonso Petite & Cura de San Miguel \\
\hline $1513-1514$ & Gonzalo Sánchez de Siles & Beneficiado en San Ignacio \\
\hline $1514-1515$ & Garcí González de Vizcaya & Beneficiado en Santa María \\
\hline $1515-1516$ & Sebastián de Justo Pérez & Cura de San Ignacio \\
\hline $1516-1517$ & Lope Rodríguez & Cura de San Pedro \\
\hline $1517-1518$ & Fernando Gómez de Córdoba & Beneficiado en San Pedro \\
\hline
\end{tabular}

${ }^{17}$ En 1503 el abad Agustín de Beteta revalidó su oficio por un año más, y durante el ejercicio 1510-1511 el bachiller Martín Alonso de Toledo, prolongó sus funciones de abad al menos un mes. ADA: ALZ 149, passim. 
En Alcaraz se pertenecía al cabildo por derecho propio al asumir el oficio vacante de cura, beneficiado o capellán en alguna de las parroquias de la población, pero con la condición de servir en persona la plaza correspondiente por un tiempo mínimo determinado. Esto implicaba en principio la obligatoriedad de residir en Alcaraz de manera más o menos continuada, motivo por el cual no todos los clérigos seculares de la población formaban parte de la hermandad. En el cabildo solían participar los curas rectores de las cinco parroquias, siendo significativa la ausencia de numerosos beneficiados servideros o simples, más tendentes al absentismo. Como muchos beneficiados vivían fuera de la población, ejercían su trabajo a través de lugartenientes y arrendaban el beneficio, en tales casos ni los titulares de los beneficios ni los sustitutos podían pertenecer a la corporación. De hecho, sólo seis o siete beneficiados de los catorce titulares integraban el grupo en el tránsito del siglo XV al XVI. ${ }^{18}$

Con frecuencia surgió el problema derivado de que los miembros del cabildo quebrantaban la residencia y se permitían más días libres fuera de Alcaraz de los que las ordenanzas estipulaban. De poco sirvió que en 1503 el abad Agustín de Beteta intentara que sus compañeros se tomasen menos vacaciones de los treinta días establecidos. Hasta entonces el calendario se contaba desde Navidad hasta la Navidad siguiente. Por lo visto, así era más difícil fiscalizar las ausencias vacacionales de los clérigos. Se intentó que se empezase a controlar a partir del día de San Miguel, pero aun así no se pudo hacer nada, por lo que se volvió a las ordenanzas antiguas en materia de días libres. No obstante, hay que valorar estos tímidos intentos de mejora dentro de lo que Azcona ha denominado la "reforma espontánea" e interna del propio clero. ${ }^{19}$

Para obtener el ingreso bastaría con habitar en Alcaraz algunos meses, como se desprende de algunos casos concretos. Sin embargo para aspirar al cargo de abad era necesaria una estancia más prolongada. De hecho, en 1516 el cabildo aprobó una ordenanza según la cual para ser abad era necesario vivir en la localidad un mínimo de tres años consecutivos o de manera interpolada. Esta norma se aprobó sin duda a consecuencias de ciertos "daños y escándalos" que se insinúa

${ }^{18}$ En 1500 , de los ocho beneficiados simples que hay en las parroquias de Alcaraz, sólo tres pertenecen al cabildo. Diez años después se mantiene la proporción.

${ }^{19}$ Azcona, T. de. 1980. "Reforma del episcopado y del clero de España en tiempo de los Reyes Católicos y de Carlos V", en R. García-Villoslada (Dir.), Historia de la Iglesia en España, III-1: 179 y ss. Madrid: B.A.C. 
ocurrieron a causa de no haberse velado adecuadamente por que los abades cumplieran un mínimo razonable de residencia. ${ }^{20}$

Pero obviamente iban surgiendo circunstancias imprevisibles. Cuando en 1508 la ciudad es alcanzada por la epidemia de peste —una de las más letales de aquella época-, el cabildo acuerda que los miembros que quieran ausentarse lo puedan hacer libremente "por ser enfermedad que se pega", y si algún capitular tomaba esa decisión tan sólo perdería la sexta parte de su ración. Pero la ordenanza daba tantas facilidades para el absentismo que dos curas cofrades se negaron a aceptarla. Estos disidentes, tras declarar que no huirían de la plaga, intentaron impedir la promulgación de la normativa, alegando que habría de aprobarse por unanimidad, como era norma en el grupo. Pero finalmente la ordenanza prosperó, pues los demás alegaron con éxito que bastaba con aprobarla por mayoría y no por conformidad de todos. ${ }^{21}$ Este asunto revela no sólo las fracturas de que adolecía la cohesión del grupo, sino también que ante casos de fuerza mayor se permitía a los clérigos el abandono de su grey y de sus funciones.

Si los clérigos hermanados querían percibir sus raciones, debían asistir a los oficios en las horas canónicas y a las ceremonias correspondientes. Así, por participar en las citadas vigilias y misas solemnes de los viernes y sábados cada capitular cobraría treinta maravedíes, y si alguno de ellos se ausentaba, su ración se repartiría entre los asistentes. Sin embargo, estos deberes se incumplieron con cierta frecuencia, lo que ocasionó más conflictos dentro del propio cabildo y la repetida redacción de ordenanzas como recordatorio de las obligaciones.

No sabemos desde cuándo se permitió la entrada de capellanes en la hermandad alcaraceña, pero en todo caso su inclusión pudo servir para evitar su organización en un cabildo específico aparte, como sucedía en otras poblaciones castellanas, y así neutralizar posibles reivindicaciones de los capellanes. Los curas y beneficiados de las iglesias de Alcaraz participaban en la corporación en pie de igualdad, mientras que los capellanes quedaban un tanto marginados, dada la categoría inferior de su oficio con relación a la de los otros clérigos. $\mathrm{Ni}$ que decir tiene que ningún capellán podía acceder al cargo de abad. No obstante, hay que subrayar el interés y la presión que debieron de ejercer las familias más poderosas de la ciudad para que los oficiantes de sus capellanías (por lo general miembros de sus propios linajes) participaran en los distintos actos organizados por el cabildo y sobre todo que

${ }^{20}$ ADA, ALZ, 149, f. 81r.

${ }^{21}$ Ibidem, f. 76r-v. Apéndice documental, nº 2. 
obtuvieran sus porciones de renta, pese a que éstas constituyeran en realidad las migajas del reparto; aunque mantener a los capellanes bajo pago de pequeñas raciones también otorgaba al cabildo capacidad de influjo sobre las familias patricias.

De acuerdo con su rango menor, las cantidades que ingresaba cada capellán correspondían a la mitad de lo que cobraban los beneficiados, como pago a su actuación en la liturgia como meras comparsas clericales. A cambio, una de sus escasas prestaciones fue la de asistir a las reuniones en que ingresaba algún capitular nuevo y tal vez también la de participar en alguna votación. Pero si en alguna junta hallamos hasta nueve de ellos (julio de 1499), ${ }^{22}$ después parece prescindirse paulatinamente de su presencia.

El ingreso de un cura o beneficiado en la corporación se efectuaba mediante un acto formal en el que todos los miembros del cabildo - 0 todos los disponibles - se reunían en una vivienda, generalmente del neófito o de algún allegado a él. En ella el aspirante a cofrade invitaba a una comida a todos los presentes, que normalmente eran los miembros del cabildo, el notario y hasta los sacristanes de las parroquias. Sin embargo, podía darse la circunstancia de que el acto tuviera lugar en Cuaresma, lo que ocasionaba no pocos problemas de conciencia o cuando menos un deseo entre los miembros del cabildo de guardar las apariencias. ${ }^{23}$ En la ceremonia, el abad del cabildo se encargaba de acoger al nuevo capitular, instándole a acatar y jurar las ordenanzas que regían la hermandad. A veces, tras el banquete el aspirante presentaba los documentos canónicos (bulas, collación, certificado arzobispal) que acreditaban su condición de beneficiado y era en ese momento cuando prestaba el solemne juramento. A continuación el abad instaba a recibir al novel en igualdad de condiciones que el resto de los componentes y el interesado pedía a los compañeros que lo recibieran y le mandasen "hacer ración", es decir, que lo acogieran y le aseguraran su parte alícuota de los beneficios de la mesa.

Como vemos, los miembros del cabildo de Alcaraz regulaban con minuciosidad cada tipo de ceremonia, lo que los señalaba como una clerecía distinguida con respecto a los no pertenecientes al grupo.

22 Ibidem, f. 72v.

${ }^{23}$ En el acto de ingreso de Alfonso Petite (marzo de 1510), se acuerda aplazar el banquete para mejor ocasión, "acatando e considerando el santo tiempo de la Santa Quarentena en que estamos, que era e es tiempo mas deçente e convenible de faser oraçiones e limosnas e otros benefiçios santos que non haser congregaçiones de comidas, e porque avia algunos benefiçiados absentes que non avian venido o non avian podido venir al dicho cabildo e congregaçion". Ibidem, f. 78v. 
Cuando falleciera algún vecino que había contratado exequias con la hermandad, en primer lugar los capitulares dirían un responso cantado y su oración en la puerta del difunto, a la que habrían acudido con la cruz propia de estos casos. A continuación, los dos beneficiados más antiguos entonaban el invitatorio, y después, cantando la letanía, todos marcharían con la cruz a la iglesia en la que se hubiere de enterrar al difunto. Al llegar a la puerta del templo interrumpirían la letanía para cantar y decir el responso Subvenite Sancti Dei; luego asistirían al proceso de sepultura y finalmente irían con sus sobrepellices a las gracias. Por su parte, en las ceremonias de memoria de aniversario se cantaba y rezaba anualmente una vigilia de tres lecturas con invitatorio y letanía; el día siguiente se haría la correspondiente misa de réquiem cantada con diácono y subdiácono; y a todo ello se podía añadir un responso semanal.

Una ordenanza de 1515 nos permite comprobar los derechos ingresados por las distintas categorías de religiosos en pago a su participación en las exequias de algún poblador que hubiera contratado previamente los servicios litúrgicos del cabildo y que, habitando dentro de la ciudad, mandaba hacerse enterrar fuera de ella. En tal caso, el abad de turno tenía que asoldar a los beneficiados con dos reales, a los capellanes de número con un real y a los clérigos extravagantes (sin oficio ni beneficio) con medio real, mientras que cada uno de los sacristanes se llevaría un cuartillo de plata. En cambio, cuando el difunto habitaba fuera del casco urbano y ordenaba hacerse sepultar en alguna iglesia o monasterio de la ciudad, las cantidades que debían abonarse a cada una de las categorías serían la mitad de las indicadas. ${ }^{24}$

Además de sus componentes eclesiásticos, la cofradía alcaraceña cuenta con su propio notario vitalicio encargado de redactar y registrar todas las escrituras relativas a la gestión del cabildo en un libro en el que recoge la recepción de donaciones, los contratos de arrendamientos de bienes inmuebles y "las vigilias e aniuersarios que el cabildo de los clerigos e capellanes de esta çibdad de Alcaras son obligados a dezir e cantar en cada vn año", algunas ordenanzas para regular el funcionamiento de la institución y asimismo las escrituras en que se registraban las ceremonias de ingreso de los nuevos capitulares. Cuando se nombraba nuevo secretario, el cabildo realizaba una sencilla formalidad con la que se le aceptaba como "hermano y notario" y se le reconocían sus particulares preeminencias y privilegios, que serían las exenciones propias del estamento eclesiástico transmitidas por los clérigos a este estrecho colaborador, por lo que el escribano podría

${ }^{24}$ El director del capítulo debía satisfacer estos pagos al tercer día de las ceremonias. Ibidem, f. 80v. 
acogerse a fuero eclesiástico. El encargado del registro figuraba como "notario dado por las abtoridades apostolicas e inperial e de los del numero de la Abdiençia Arçobispal" de Toledo, para la ciudad de Alcaraz y su arcedianato. ${ }^{25}$ Pero su carácter de notario apostólico no le confería necesariamente condición de eclesiástico; de hecho solía ser seglar y llevar vida conyugal.

A finales del siglo XV y principios del siguiente figura como notario Juan González de Vizcaya, quien afirma ostentar el cargo a perpetuidad, si bien en ocasiones aparecen elaborando los documentos otros notarios (Fernando García, Fernando de Bracamonte), que más bien reemplazan a Vizcaya en alguna circunstancia accidental. Tengamos en cuenta que este a veces tiene que acudir a seguir pleitos fuera de la ciudad. Después, hacia 1514 y acaso por fallecimiento, el notario Vizcaya desaparece de las fuentes. Para entonces ya estaba siendo sustituido con más frecuencia. Los años inmediatamente posteriores ejercieron un amplio número de secretarios (Fernando García, Antón de Quesada, Gonzalo de Peñarrubia, Alonso Cano, Pedro de Mesto...), lo que podría delatar dificultades para designar un notario fijo. ¿Conflictos de candidaturas, retrasos burocráticos?

Financiación: bienes y rentas

Con su vistoso ceremonial, el cabildo aportaba boato y magnificencia a la vida cotidiana de los sencillos alcaraceños, bajo un fascinante refinamiento que ciertamente los cautivaría captando su atención y asegurando con más firmeza sus voluntades. Para garantizar el cumplimiento de los clérigos con las horas canónicas y el resto de ceremonias, la corporación se dotó de un preciso reglamento y también de todo un conjunto de bienes materiales y rentas monetarias procedentes en su mayor parte de donaciones que se destinaban exclusivamente a gratificar a sus componentes.

Esta consistente hermandad adquirió al término del Medievo una fuerte posición en la ciudad no sólo en el plano litúrgico, sino como propietaria de varias decenas de inmuebles y como adjudicataria de negocios. Se puede con ello afirmar que el patrimonio de la cofradía de Alcaraz superaba al de cualquier fábrica parroquial, erigiéndose con ello en uno de los principales propietarios de la ciudad. Menos probable es que aventajase a los conventos franciscanos y dominicos implantados en la ciudad, a tenor de las enormes pertenencias que estos reunieron al poco tiempo de sus respectivas fundaciones. Pero pese a dicho patrimonio y al ambiente de reforma interna, la caridad cristiana parece descuidarse en la hermandad alcaraceña, y en este sentido, cierta

${ }^{25}$ Ibidem, f. 7r. 
limosna que en 1497 otorgó para la cría de un niño abandonado hay que interpretarla como una excepción a la norma.

Entre las fuentes de financiación que acaparaba el cabildo a finales del cuatrocientos se encuentran algunas rentas paradiezmales obtenidas en ciertos cortijos asignados, además de algunos inmuebles rústicos y urbanos, más la institución de memorias asociadas a muchos de los bienes raíces recibidos a través de donaciones piadosas.

En el momento de su constitución, el cabildo recibió la merced de sustentarse con las rentas procedentes de lo diezmado en veintisiete caserías, a saber: cortijos más o menos aislados que estaban apartados de la jurisdicción parroquial y que por tanto no tributaban en los diezmos comunes. ${ }^{26}$ Sin embargo, a finales del siglo XV algunos de estos lugares se habían despoblado y los que entonces tributaban eran veinticuatro reunidos en dieciséis dezmerías o unidades de percepción tributaria. ${ }^{27}$ De tales poblados el cabildo alcaraceño extraía y arrendaba un atípico diezmo que gravaba el pan, la miel, la cera y el pastel. De lo recaudado, dos tercios iban a parar al mantenimiento de los componentes de la hermandad, mientras que el resto lo percibía el arzobispo en exclusiva. A este diezmo se añadían también las primicias en las mismas dispersas caserías, que los clérigos arrendaban, creemos, por periodos prolongados. ${ }^{28} \mathrm{El}$ cómodo mantenimiento de estas rentables fuentes de ingresos propició que tanto el arzobispo como los clérigos de la cofradía de Alcaraz se resistieran a la creación de nuevas parroquias en esos parajes, una agravante para el estancamiento administrativo de que

${ }^{26}$ Pérez de Pareja, E. 1740. Historia de la primera fundación de Alcaraz y milagroso aparecimiento de $N$. Sa de Cortes: 108. Valencia: Imp. Joseph Thomas Lucas. Este autor afirma que fue Alfonso VIII quien dotó a la cofradía con sus rentas decimales, aunque probablemente Jiménez de Rada determinó su financiación original.

27 En esta época las caserías eran: Turruchel, Montemayor con La Declaración, Fuente El Berro, La Ventosa, Navaluenga, Torrepedro con Morote, Sacedilla, Fuente la Carrasca con Peñarrubia y la Casa de Alvar González, Casa de los Hontanares con el Río Mundo, Elche de la Sierra, Casa de Mencía Sánchez, Los Sotillos, El Cerro del Caballo y Prados Anchos con el Río de Pinilla, Santa María de Yunquera, Fuentelapuerca, El Hardal "çerca de Las Matanzas" y Campillo de Oncebreros. Guadalupe Beraza, M. L., 1972, Diezmos de la sede toledana y rentas de la mesa arzobispal (siglo XV): 97. Salamanca: Universidad de Salamanca; Archivo de la Catedral de Toledo: Obra y Fábrica, libro 359, ff. 232r-v.

${ }^{28}$ En 1510 el cabildo arrendó esta renta a Agustín de Bonjorne y Juan Cobo, que entregaron cada año nada menos que 2.000 mrs. 
adolecía la diócesis. ${ }^{29}$ Por ello, esta circunstancia, que podría parecer síntoma de desestructuración territorial, perduró hasta los tiempos modernos.

Al mismo tiempo la cofradía se convirtió en beneficiaria de ciertas rentas que se obtenían en el término de Alcaraz a expensas de otras actividades. Por ello, percibía dos tercios de las rentas del llamado menudo de los ganados extranjeros que herbajaban en suelo del arcedianazgo, quedando el otro tercio para el arzobispo de igual forma que se repartían los diezmos de las caserías.

Por otra parte, desde su institución y una vez que al cabildo de Alcaraz se le concedieron las rentas de las caserías, se fueron añadiendo las donaciones que diferentes particulares traspasaron al cuerpo capitular. Casi todos los inmuebles que el cabildo poseía procedían de particulares que los entregaban inter vivos o por vía testamentaria en plena propiedad para que los clérigos los pudieran poner a la venta o más bien para que los cediesen en arriendo o bajo censo enfitéutico a terceros. Asimismo, el cabildo estableció censos consignativos como forma de crédito ofrecido a campesinos, de modo que los eclesiásticos dispusieron de unos ingresos situados sobre bienes, generalmente raíces. Otras veces, aunque tampoco fuera la tónica general, la cofradía compró inmuebles o bien tomó heredades en alquiler para subarrendarlas a campesinos y obtener así un beneficio rápido y de bajo riesgo. Aparte de estos métodos tan comunes, se ingeniaron acuerdos más pintorescos y anecdóticos que podrían considerarse como una forma de dotación de los clérigos, como el banquete que el notario Juan de Siles se obligaba a ofrecerles periódicamente por disfrutar de una huerta del cabildo. ${ }^{30}$

En cuanto a los inmuebles que los capitulares atesoraban en la ciudad de Alcaraz, predominan los emplazados en las zonas de ensanche en que habitaban menestrales y otros sectores dinámicos de la sociedad local y donde se situaban los principales establecimientos comerciales y profesionales de la población. Llama la atención la cantidad de fincas que el cabildo poseía en las principales calles y plazas de la ciudad (calles Mayor, de la Zapatería, Real, Sierpe, plaza Mayor, de La Trinidad...). Se trata de las vías de mayor valor catastral, con casas de poca antigüedad y cámaras para su explotación económica, lo que para los clérigos suponía una innegable ventaja a la hora de acometer negocios inmobiliarios. A veces incluso consiguieron hacerse con

29 Sobre el anquilosamiento burocrático de la diócesis toledana, vid. Ayllón Gutiérrez, C. 2002. "Sobre las parroquias de la tierra de Alcaraz a finales de la Edad Media", Cultural Albacete 12-13: 30.

${ }^{30}$ ADA, ALZ, 149, f. 27v. 
inmuebles contiguos, redondeando y revalorizando con ello las fincas, tal como también hacían en suelo rústico.

La cesión de una casa o tienda al cabildo venía acompañada del acostumbrado ritual. Como representante de la corporación, el abad solo o en compañía de alguno de los prebendados, era conducido por el otorgante a las puertas del inmueble y tomaba posesión del mismo entrando en la estancia y encerrándose en ella durante unos instantes, haciendo de los gestos expresión pública de lo plasmado por escrito. ${ }^{31}$

Resulta harto significativo que entre las casas del cabildo no figure ninguna cámara en la que se celebren sus reuniones, una carencia que se explica por la facilidad con que los clérigos utilizaban las parroquias de la ciudad, ya que cualquiera de ellas estaba disponible como escenario de sus reuniones. De hecho en todas se rubricaban indistintamente los contratos de arrendamiento de bienes inmuebles o los de establecimiento de memorias de aniversario. Diríase incluso que las iglesias se rotaban como sede de las juntas. Lo cierto es que la parroquia donde se organizaba la reunión no tenía por qué guardar relación con los contratantes ni con las futuras misas funerarias. Asimismo, las lúdicas ceremonias de ingreso de los nuevos beneficiados se realizaban, como se ha señalado, en la morada del neófito, de un familiar o de algún allegado a él. Pero lo que más nos importa es el hecho de que la hermandad aprovechaba sus medios para evitar adquirir un inmueble específico, lo que redundaba en su provecho.

Por otra parte, también el cabildo de Alcaraz acaparó numerosas propiedades agrarias, todas en parajes cercanos al núcleo urbano y muchas en las zonas más fértiles del término, las situadas en la ribera del río Guadalmena o en otros lugares bien abastecidos de agua (arroyo de Gonzalo Ruiz), pero en general en las proximidades de la ciudad (Vado de Reolid, El Retamal, La Noguera). Gran parte de las tierras les eran cedidas en arriendo, debiendo el concejo de la ciudad asegurar con

31 Así se recoge, por ejemplo en 1499, cuando el abad Grajal y Calderón, cura de Santa María, tomaron posesión de las dos casas terreñas que Juan Sánchez de Siles y su esposa, Elvira Ruiz de Alcalá, les habían cedido en la calle de la Zapatería: "Juan Sanches de Siles tomo por la mano al dicho señor bachiller Garçia de Grajal, abad del cabildo, e entregole la posesyon de las dichas tiendas. $E$ en señal de posesyon entro dentro de las dichas casas el dicho señor bachiller e el dicho Gregorio Calderon en nombre del dicho cabildo, e çerraron e abrieron las puertas de las dichas tiendas e dixeron que se tenian por contentos de la dicha posesyon, e que lo pedian por testimonio, a lo que fueron testigos presentes el bachiller Pedro Covo e Juan Ruis Alcantud e Grabiel Calderon, veçinos de la dicha çibdad de Alcaras". Cfr.: Ibidem, f. 1v. 
inspecciones el buen uso y estado de las heredades, un insólito servicio público que probablemente se remontara a la época fundacional. Por lo que respecta a su duración, el arrendamiento generalmente se establecía por dos vidas: es decir el tiempo que vivieran el contratante y un heredero suyo, una vez que el primero falleciera; pero aunque muchos alquileres se convinieron por estas dos vidas, cuando al cabildo (o a ambas partes) le interesaba romper con este requisito, y esto es algo que ocurría con cierta frecuencia, se disolvía lo firmado. Por su parte, los arrendatarios eran generalmente pequeños campesinos sin que parezca crearse en este sentido unos lazos especiales entre el cabildo y los grupos locales de poder.

En los contratos de tierras junto al río se pedía encarecidamente ya no sólo que los usufructuarios mantuvieran en buenas condiciones los predios "a guisa de buen labrador", sino que cuidasen especialmente la parte de "la hondonada", siempre más expuesta a crecidas. Por lo demás, algunas de estas familias censualistas utilizaban la riqueza de las fincas agrarias recibidas del cabildo para complementar los ingresos que recibían por sus profesiones (como sucedía con la familia de los Jubeteros, que tuvieron que acentuar sus labores agrícolas cuando el reino atravesó épocas más pacíficas y por tanto menos rentables para su oficio). Otras veces se trataba de clérigos alcaraceños, pertenecientes o no a la cofradía, quienes fueron arrendatarios preferentes de estas fincas. Por otra parte, también los propios eclesiásticos o su parientes donaban con cierta frecuencia tierras al cabildo, a quien considerarían muchas veces el heredero más apropiado. ${ }^{32}$

De acuerdo con lo producido, estas parcelas por lo general eran huertas que poseían trigo, olivos, serbales y otros árboles, y en mayor medida viñas y parrales. ¿Acaso había un considerable consumo de vino? En realidad la entrega de viñedos a los clérigos se basaba en la asociación del vino con la sangre redentora de Cristo, como ya advirtiera Guerreau. ${ }^{33}$

También los clérigos de la hermandad de Alcaraz se lanzaron al campo de la especulación inmobiliaria tomando en arriendo heredades ajenas. En efecto, en 1504 solicitaron al concejo el arrendamiento de la dehesa de Turruchel, perteneciente a los propios de la ciudad. El trato se

32 Una fanegada de tierra y viña situada en el paraje de El Retamal, con tres pares de olivos, fue entregada en 1506 por la hermana de cierto clérigo llamado Fernando Gutiérrez, de quien la había heredado. Tras recibirla, el cabildo la arrendó de inmediato al hortelano Pedro Sánchez de La Matilla por 60 maravedíes.

${ }^{33}$ Guerreau, A. 2002. El futuro de un pasado: 144. Barcelona: Crítica. 
cerró fijándose una renta anual de 11.000 maravedíes. ${ }^{34}$ Con esta maniobra el control de las fuentes de riqueza de Turruchel por parte del cabildo se hizo absoluto, pues éste ya percibía dos tercios de los diezmos de pan, cera, miel y pastel de este paraje, ya que se trataba de una de las caserías que abastecían económicamente a la hermandad de los eclesiásticos. Pero una semana después del contrato, el síndico del concejo exigió la inminente paralización del aprovechamiento de la finca, dado que los clérigos, abusando de su venerada consideración social, se hicieron cargo de la dehesa sin haber dado las fianzas correspondientes de la renta.

No obstante, la mayoría de las fincas rústicas y urbanas del cabildo procedían de las numerosas memorias instituidas en favor de la cofradía alcaraceña. De algunas de ellas se perdió progresivamente el rastro documental e incluso el recuerdo por parte de los oficiantes, que no obstante siguieron disfrutando de las rentas que generaban los bienes recibidos para oficiar dichas memorias. Así pues, no se pueden disociar las propiedades inmuebles con respecto a estos oficios sacros debido al entramado de operaciones financieras que se asientan para propiciar la financiación de la propia cofradía.

Entre las memorias que el cabildo celebraba destaca la fundada a finales del siglo XIV por Juan Sánchez Manuel, conde de Carrión, que rentaba tres millones de maravedíes anuales. Mucho después, en el tránsito del siglo XV al XVI, tenemos el caso referido de las casas, con un local para tienda, cedidas en 1499 por Juan Sánchez de Siles y su esposa, en el que su renta tendría que destinarse a una memoria perpetua, bajo las condiciones litúrgicas habituales. ${ }^{36}$

34 Archivo Municipal de Alcaraz: leg. 14, A.C. 10-noviembre-1503; 4diciembre-1503; 12-marzo-1504; 24-marzo-1504. La dehesa de Turruchel, en otros tiempos de uso comunal, fue transformada en bien de propios para que el concejo de Alcaraz la pudiera arrendar, iniciando así un proceso de restricción de su uso a los campesinos, y de tráfico de influencias con respecto a los adjudicatarios. En el cambio de centuria, Turruchel se revalorizó considerablemente pues frente a los $11.000 \mathrm{mrs}$ en que se tasó a principios del XVI, se hallan los 6.000 en que se había arrendado en 1494. García Díaz, I. 1987. Agricultura, ganadería y bosque. La explotación económica de la tierra de Alcaraz (1475-1530): 55-60. Albacete: IEA.

${ }^{35}$ Archivo Municipal de Alcaraz: leg. 14, A.C. 26-marzo-1504.

${ }^{36}$ Se establece "que los benefiçiados e capellanes de esta dicha çibdad (...) perpetuamente para siempre jamas, sean thenudos e obligados de desir e cantar cada vn año en la yglesia de San Pedro el dia de San Pedro e San Pablo a las bisperas una vigilla de tres liçiones con su vitatorio e letania, e otro dia syguiente vna misa de requiem cantada con su responso segund que el 
Con esta dinámica y dados los problemas económicos de muchas familias, el cabildo de Alcaraz generalizó la recepción de capital con la creación de censos consignativos no redimibles, una operación financiera más compleja y rentable de lo que hubiera sido el simple cobro de limosnas. El otorgante de la donación monetaria era el que encargaba las memorias, y el cabildo buscaba a un tercero necesitado de liquidez para entregarle el dinero a modo de crédito. Los clérigos no tardaban en encontrar campesinos a quienes otorgárselo, los cuales se obligaban a entregar un censo a perpetuidad hipotecando los bienes raíces de donde se obtenía la renta. El otorgante además era quien fijaba la cuantía del censo, y lo obtenido por la liquidación o por el alquiler o acensamiento de las propiedades pasaba a engrosar las raciones de los cofrades. A cambio, el cabildo se obligaba a decir misas por el alma del donante y las de quienes este hubiera señalado en el contrato o en el testamento. Y como hemos señalado, muchas veces los implicados en estas operaciones - los censaleros o los otorgantes del capital- eran clérigos, como ocurría con otras actividades económicas del cabildo.

En cualquier caso, resulta oportuno revisar algunos casos que nos ilustran sobre este tipo de procedimientos. Por ejemplo, en 1507 el carnicero Alfonso de Siles y su hijo Juan, clérigo, recibieron cinco mil maravedíes donados por Juan Sánchez de Montiel para costear una memoria. Nueve años más tarde Martín de Arenas entregó otros cinco mil maravedíes (lo que parece una cifra estandarizada) "para que se comprasen tresientos maravedis de sense" a fin de que el cabildo dijese una vigilia en la iglesia de San Ignacio en su capilla familiar de Nuestra Señora de la Paz. El dinero fue entregado a un matrimonio de la aldea de Ayna, que se comprometió al pago anual de trescientos maravedíes de censo por toda su vida. ${ }^{37}$ Cabe resaltar que la familia de Martín de Arenas atravesó considerables apuros, habida cuenta de su militancia anti-isabelina y posible origen converso, aspectos que incidieron en ciertas maniobras de mayor acercamiento a la clerecía local. Entre ellas, en 1518 un Gonzalo de Arenas compareció de nuevo ante el cabildo para asentar un aniversario, establecido con su mujer, Leonor de Alcalá, para que se dijese una vigilia anual en San Ignacio, y al día siguiente se celebrase y cantase una misa en su citada capilla. ${ }^{38}$ Asimismo, el

dicho cabildo tiene en constumbre, e asymismo el dicho cabildo sea obligado de mandar doblar en todas las yglesias". Cfr.: ADA: ALZ 149, f. 1r.

37 Ibidem, f. 31. El matrimonio dio por fiador a su convecino Alonso García de Vandelvira.

38 Ibidem, f. 39r. Con la dotación de $400 \mathrm{mrs}$. anuales, los cofrades habrían de cobrar una ración, los capellanes media, y cinco maravedíes los sacristanes, que debían hacer doblar las campanas de sus iglesias como de 
licenciado gallego Alonso Rodríguez de Estrada, cura de La Trinidad y miembro del cabildo de Alcaraz, instituyó en julio de 1518 una memoria, para cuya financiación destinó diez mil maravedíes con los que poder adquirir un censo. En septiembre se cerró un contrato con otro matrimonio de la ciudad que entregarían un censo perpetuo de setecientos cincuenta maravedíes, tomados de unas casas en el casco urbano alcaraceño. ${ }^{39}$ Pero no fue este el único caso en que un cofrade legara buena parte de su patrimonio a la hermandad. ${ }^{40}$

Por último, el cabildo recibió algún censo como el concertado con el comendador Sebastián de Arroyo, quien poseía un mesón extramuros de la ciudad en la parte de la puerta de las Torres, cerca de las Cantarerías. El establecimiento lo regentaba el regatero Pedro Ruiz, que pagaba 4.200 maravedíes de censo al comendador y este a su vez transfería de esta cantidad 260 maravedíes al cabildo. Arroyo hizo la donación en enero de 1506 para que se dijera todos los años por él y por sus difuntos el día del Corpus una vigilia de tres lecturas con su letanía y otro día una misa de réquiem, en la capilla de García González de Vizcaya y de su mujer, en la Trinidad, que pusieran sobre su sepultura la "crus negra de la dicha yglesia e faser doblar segund costumbre a la dicha vegilia e misa", y que los 260 maravedíes los diesen al abad capitular de turno. En consecuencia, las distintas partes afectadas quedarían como sigue: el comendador Arroyo se mantenía como propietario del dominio eminente del mesón y de la renta con que estaba gravado, Pedro Cobo seguiría como dueño del dominio útil (usufructo) del negocio, aunque Arroyo percibiera 3.940 maravedíes como beneficiario de una parte de la renta, mientras que el dueño del usufructo del resto de la renta (260 maravedíes) sería el cabildo. ${ }^{41}$

costumbre. Desde 1519, la vigilia (de tres lecciones con invitatorio y letanía) se hizo el día de San Ildefonso.

39 Ibidem, ff. 33v-34v. La vigilia se realizaría el día de la Transfiguración del Señor (6 de agosto) en la capilla mayor. El censo lo pagaría el matrimonio y después sus sucesores. No deja por lo demás de sorprendernos que Estrada añadiese en la escritura que el cabildo le debía ciertas cantidades que él hubo prestado en febrero para la fábrica de "Santi Yuste" de Alcalá de Henares. Esto apunta a que el arzobispado de Toledo pidió al cabildo una aportación para esa iglesia y Rodríguez de Estrada adelantó todo o una parte, aunque luego perdonó la deuda. Nos inclinamos a pensar que los clérigos abusaron del patrimonio y de la buena fe de su veterano compañero para no verse afectados por la solicitud de dinero por parte de Toledo.

40 El cura Alonso de Claramonte dejó asentada por entonces una memoria familiar de 10 misas. Más detalles en Ayllón Gutiérrez, C. 2009. "Los Soriano: otro linaje eclesiástico en el cabildo de Cartagena", Murgetana 120: 107.

${ }^{41}$ ADA: ALZ 149, 11v-12r. 
Así pues, las formas de sufragar los aniversarios fueron diversas. Desde la simple donación de bienes con cuyas rentas se pudieran financiar los oficios, hasta la recepción pasiva de censos pagados por terceros. Pero más habitual fue la institución de censos consignativos o censales para que los clérigos pudieran adquirir rentas a largo plazo o a perpetuidad. Si los campesinos no podían hacer frente a los pagos, sus propiedades quedaban amortizadas en manos de los cofrades, lo que contribuyó a la formación de un considerable patrimonio inmueble por parte del cabildo de Alcaraz.

Todo este acaparamiento material unido a la reputación de los oficios clericales otorgó a la hermandad tal notoriedad que cuando en 1519 el concejo, en pleno proceso de ampliación de la plaza Mayor, decidió expropiar una casa cuya renta estaba destinada a cierta capellanía (a todas luces oficiada por los capitulares), algunos regidores temieron enfrentarse al cabildo de beneficiados y abandonaron la decisión. Un ejemplo que ilustra el prestigio y la autoridad alcanzados por sus miembros. ${ }^{42}$

COFRADÍAS CLERICALES EN LA MANCHA CONQUENSE. LA ABADÍA DE TRESJUNCOS

Contigua a la tierra de Alcaraz, en la Mancha conquense destacó por encima de todas las hermandades de clérigos el cabildo (o abadía) de Tresjuncos, presuntamente fundado en el pueblo homónimo de donde tomó su nombre. Estaba constituido por los curas (y algún beneficiado simple) destinados en varias parroquias de la tierra de Belmonte, los cuales se agruparon aquí también para proporcionar cierta pompa a algunos oficios religiosos, obtener con sus actividades unos beneficios accesorios y salvaguardar sus derechos.

Las noticias más antiguas de que disponemos acerca de este cabildo se remontan a $1397 .{ }^{43}$ Sin embargo existen testimonios en unos inventarios de 1411 en los que uno de los presentes afirma que su bisabuelo donó ciertas tierras a la cofradía, hecho que se situaría a lo más tardar a mediados del siglo XIV. Quizá sus orígenes haya que buscarlos con ocasión de los virulentos brotes de peste de mediados del

42 Pretel Marín, A. 2010. "La Plaza de Alcaraz y la carrera artística de Andrés de Vandelvira", Homenaje a Alfonso Santamaría Conde: 461. Albacete: IEA.

43 Archivo Parroquial de Las Pedroñeras: C. 15: C-3 (En lo sucesivo: "Libro del cabildo de Tresjuncos"). Este volumen, que recoge documentos diversos de la cofradía (entre 1397 y 1598) constituye la principal fuente de información sobre la misma. 
siglo XIV, que condujeron a muchos pobladores de Europa que quedaron sin parientes, a donar sus tierras a fin de que los eclesiásticos rogaran por sus almas en una situación de frágil esperanza de vida. Asimismo, los propios clérigos debieron de participar del mismo temor que los demás mortales a la hora de asociarse ante la circunstancia de fallecer sin nadie que pudiera rezar por sus almas. Este miedo a morir a solas fue uno de los detonantes más significativos del movimiento de fundación de cofradías; ${ }^{44}$ pero tampoco hemos de descartar que la defensa de los privilegios eclesiásticos frente a la pujante nobleza fuera uno de los factores de constitución de este tipo de hermandades, lo que no podemos desdeñar en una época en que la tierra de Belmonte se halla bajo el señorío del poderoso don Juan Manuel.

Para 1420 se constata un propósito de regeneración en la cofradía, por lo que en noviembre -y ante el vicario de Belmonte como máxima autoridad eclesiástica de la comarca- se decidió redactar unas nuevas ordenanzas "con entençion de reformar munchas cosas que estauan menguadas en el dicho cabillo, asy çerca de lo espiritual commo en lo tenporal" y "a fyn que el seruiçio de Dios e de la su Iglesia fuese e sea acresçentado, e el pueblo acreçentase en buena deuoçion". ${ }^{5}$ Después tuvo que llegar el final de la centuria para que el cabildo sufriera una nueva crisis con la intromisión de la iglesia colegial de Belmonte en su economía, composición y funcionamiento.

\section{Los componentes del cabildo}

La cofradía se componía de un abad, un prior (o piostre) y cerca de una decena de clérigos beneficiados, además de un auxiliar que ejercía de notario, quedando todos sujetos a un minucioso reglamento.

El abad dirigía la hermandad, estaba obligado a visitar sus propiedades inmuebles y en su caso deslindarlas, aplicar penas "pecuniales" a los cofrades infractores, imponer orden y silencio en los momentos debidos y arbitrar en conflictos internos que pudieran surgir en el seno de la abadía. Asimismo, gestionaba las cuentas, cobraba las rentas (previamente recaudadas por los distintos clérigos) y distribuía las raciones entre los componentes, y por todo ello tenía un salario adicional a las raciones que repartía. En este sentido las ordenanzas de 1420

44 Le Goff, J. 2003. En busca de la Edad Media: 142 Barcelona: Paidós.

${ }^{45}$ Apéndice documental, $n^{\circ} 1$. Las ordenanzas de 1420 detallan multitud de aspectos de la gestión de la cofradía, no todos ellos reflejados en el presente trabajo. Libro del cabildo de Tresjuncos, ff. 85 y ss. 
indicaban que para su "pitanza" y "por su trabajo" debía cobrar ciento cincuenta maravedíes. ${ }^{46}$

Presidía la ceremonia anual en la que se abordaban las cuestiones más relevantes para el grupo, entre ellas la elección del nuevo abad, siendo en esta ocasión cuando el director saliente entregaba al nuevo el libro de censos y ordenanzas como símbolo de su poder eclesiástico y económico. No es fácil saber el criterio seguido a la hora de elegir abad. Lo cierto es que aquí tampoco se trata de un cargo rotatorio, pese a que en la elección de octubre de 1512 se señale que se elige abad "en horden de su año". Lo cierto es que algunos clérigos integrantes nunca resultaron designados abades, mientras otros repitieron en el cargo con relativa frecuencia.

Algo más difusa es la figura de un prior, una figura auxiliar del abad que debía tomar prendas a los cofrades que incurriesen en penas; y que sobre todo se encargaba de gestionar los banquetes que los clérigos disfrutaban en su reunión anual ordinaria. Las fuentes también nos hablan de un piostre, aunque todo apunta a que se trata de la misma persona, que tenía unas funciones un tanto elementales como por ejemplo tomar "lo menudo de todas las reses que se matare menudas e el pellejo e una cola de cada res sacada segund costumbre antigua". ${ }^{47}$

Por su parte, el notariado lo ejercía un clérigo con carácter vitalicio. Entre 1475 y 1493 lo desempeñó un tal Pedro García (que casi nunca declara su condición eclesiástica y que no era cofrade stricto sensu). Ese último año pasó a uno de los componentes del propio cabildo, el chantre Guerrero, lo que acentuó el hermetismo del grupo con respecto a elementos externos y confirmó el protagonismo de este clérigo que acababa de ingresar en la abadía y pertenecía a la ambiciosa colegiata de Belmonte.

Ahora bien ¿quiénes podían ingresar en el cabildo de Tresjuncos? En principio eclesiásticos con oficio en algunas iglesias próximas a Belmonte, en concreto Tresjuncos, Las Pedroñeras, el Pedernoso, Robledillo de Záncara, Hontanaya, Las Mesas, El Hinojoso del Marquesado, Monreal, La Ossa, La Puebla de Almenara, Villaescusa de Haro, La Aceñuela y, ya en el siglo XVI, La Poveda. Además, en el cabildo también participaron beneficiados servideros de Villaescusa, Tresjuncos y Hontanaya, mientras que otro clérigo de igual categoría existente en El Pedernoso no estaba incluido en la hermandad. Todas las poblaciones citadas estaban servidas por sendos curas que en virtud de

46 Ibidem, f. 87v. Se trata de lo que en Alcaraz se conocía como derechos de preste y abadía.

${ }^{47}$ Ibidem, f. 88r. 
su oficio pertenecían al cabildo. Por lo demás, en su composición quedaban excluidos los capellanes. Sin embargo, no resulta fácil definir qué criterio determinaba la vinculación de estas parroquias, y no otras, a la cofradía. Se diría que los clérigos de la tierra de Belmonte desearon unirse ante la pujanza que la iglesia parroquial de esta villa fue adquiriendo y con ella su capacidad de atraerse limosnas y oficios funerarias generosamente dotados.

Quizá por haberse fundado en Tresjuncos, el cura de esta población gozaba de cierta preeminencia sobre los demás, lo que no es de extrañar puesto que el sacerdote del momento fundacional debió de tener responsabilidad directa en la puesta en marcha de la cofradía. De ahí que se constate que Tresjuncos "es prinçipal lugar del dicho cabildo".

La pertenencia al cabildo era vitalicia, aunque en algunas ocasiones el grupo aceptó la renuncia al puesto por razón de avanzada edad o salud precaria, que impedían el buen desempeño de las funciones en la cofradía. Por otra parte, para formar parte del cabildo y como condición indispensable para cobrar las raciones, a los clérigos integrantes se les exigía la atención directa en su parroquia (no a través de un lugarteniente), aunque se concedía más importancia a su asistencia a las reuniones del cabildo. Pero a finales del siglo XV, la inasistencia a la junta va en aumento y ya en 1484 el abad Francisco de Molina y Ruy Gómez de Anaya, miembros del cabildo catedralicio de Cuenca y de la abadía de Tresjuncos, decidieron regular junto al abad con más precisión este problema. ${ }^{48}$ Sin embargo, en 1498 el absentismo en las reuniones anuales perdura y, en consecuencia, los clérigos más cumplidores exigen que se obedezca cierta ordenanza redactada nueve años atrás.

El ingreso de un nuevo componente tenía lugar en la reunión ordinaria anual del cabildo. Cuando uno de los oficios parroquiales de las iglesias vinculadas a la abadía era cubierto, el nuevo titular esperaba a la junta siguiente para comparecer y solicitar su ingreso, jurando respetar las ordenanzas. Para poder entrar en la hermandad, el neófito debía haber cantado misa a lo largo del primer año de oficio en la parroquia, o bien se comprometía a hacerlo durante el año en curso.

Entre las obligaciones a que estaban sometidos estos clérigos hay que señalar su obediencia al abad y la asistencia a la junta anual en la que debía vestir sobrepellices. Asimismo, cuando uno de ellos fallecía, los demás compañeros debían asistir en su entierro: cinco cofrades eran llamados por el abad (o por el piostre) para que acudieran a lavar el

${ }^{48}$ Ibidem, f. 91r-v. 
cuerpo, amortajarlo, enterrarlo y hacer los oficios correspondientes con vigilia de nueve lecturas y letanía. Por otro lado, cuando el abad visitaba las propiedades raíces del cabildo, el cofrade que tenía oficio en el correspondiente pueblo debía procurarle comida (así como cebada para su mula), pues el superior no debía afrontar ningún gasto referente a la gestión de dichas propiedades inmuebles. Además los hermanados debían asumir ciertas prohibiciones -que eran sancionadas por el abad-, como la de jugar a los dados durante los días en que se celebraba la junta anual, así como ofender a compañeros o discutir con ellos. A la citada reunión tampoco debían hacerse acompañar de más de una persona, que por lo general era el sacristán de su iglesia.

El incumplimiento de las obligaciones llevaba aparejado determinadas penas pecuniarias $y$, aunque el abad se encargaba de aplicar las sanciones, hubo momentos en que la comisión de faltas canónicas llegó a tales extremos que algunos cofrades cayeron en la excomunión, como sucedió en 1510, momento en que el castigo bien pudo venir por causa de los conflictos que enfrentaron a los de Tresjuncos con los de Belmonte, pero que en todo caso se vio acompañado de un adelanto en la elección del abad a finales de dicho año para el siguiente ejercicio. ${ }^{49}$

Organización y gestión interna.

La dinámica litúrgica y organizativa del cabildo giraba en torno a un momento concreto del año, aquel en que tenía lugar la junta ordinaria de sus componentes. Durante mucho tiempo esta reunión fue denominada sex o seis, aunque esta nomenclatura se va perdiendo a medida que avanza el siglo XV. Cabe entender que este singular nombre se debe a que durante cuatro días consecutivos los clérigos realizaban seis ceremonias -3 oficios y 3 misas - en varias poblaciones relacionadas con la cofradía. ${ }^{50}$ Sin embargo, el ritual se fue simplificando a lo largo del tiempo y, si en un principio eran cuatro los lugares entre los que los clérigos tenían que ir haciendo su periplo durante esos días, a finales del siglo XV no parece que el ceremonial sea tan extenso, puesto que se reducen los días y lugares de celebración.

${ }^{49}$ Ibidem, f. 43r.

${ }^{50}$ Por ejemplo, en abril de 1475 se proyecta que para el año siguiente se hagan las ceremonias con arreglo al siguiente calendario: el lunes por la tarde, oficios en Tresjuncos; el martes por la mañana, misa en Las Mesas; por la tarde, oficios en La Ossa; el miércoles por la mañana, también en La Ossa misas; y en Monreal después de comer, oficios; el jueves en Monreal, misas. Ibidem, f. 1v. 
Lo cierto es que todos los años los cofrades se reunían para realizar estos actos y para poner los medios con que regirse durante el ejercicio siguiente. Podríamos trazar un aproximativo orden del día habitual de estas juntas, en las que confluían actos sagrados y organizativos. Así, convocados por el abad con suficiente antelación, los clérigos hermanados se dirigían al pueblo que se había designado el año anterior para realizar el sex. En la junta del 1475, esta antelación se estableció en quince días.

Los lunes tenían lugar los oficios de vigilia, a los que acudían los clérigos que vivían más cerca del lugar escogido para ello; y ya el día siguiente tenía lugar el sex, esto es, la junta propiamente dicha con una misa previa a la que debían ya acudir todos los cofrades. En esa junta tenía lugar la elección del nuevo abad, previa deliberación de los eclesiásticos. Una vez designado el director, los demás compañeros debían hacer expresión de acatamiento y besarle la mano. A continuación ingresaban los nuevos miembros (que lo eran por lo general, como se ha señalado, por fallecimiento de sus antecesores en los respectivos beneficios parroquiales), aunque dado que son poco numerosos los componentes del cabildo, muchos años no hay ingresos o sólo lo hace una persona. Para hacer el ingreso, el neófito hacía la solicitud verbal, que era respondida con la aceptación de los demás compañeros; y a continuación prestaba juramento de obediencia al abad y las ordenanzas en actitud de sometimiento, besaba la mano al abad y hacía entrega de la "entrada", es decir, una cuota de ingreso que consistía en ofrecer al cabildo y a su costa una cena (que tendría lugar la misma tarde en que se realizase su ingreso), más el desembolso de una cantidad en metálico (que en 1420 era de cincuenta maravedíes) y una libra de cera para la liturgia de la abadía. ${ }^{51}$

Una vez elegido el nuevo abad y admitidos los nuevos compañeros, el superior saliente le entregaba a su sucesor el libro de censos, posesiones, ordenanzas y actas, y luego se llevaba a cabo, si procedía, la redacción de nuevos estatutos para mejorar el régimen de la abadía.

CUADRO 2

ABADES DEL CABILDO COMARCAL DE TRESJUNCOS (1492-1518) ${ }^{52}$

\begin{tabular}{|l|l|l|}
\hline \multicolumn{1}{|c|}{$\begin{array}{c}\text { AÑO (fecha } \\
\text { elección) }\end{array}$} & \multicolumn{1}{c|}{ ABAD } & \multicolumn{1}{c|}{ OFICIO CLERICAL } \\
\hline 1492 & $\begin{array}{l}\text { Diego García de } \\
\text { Torrejoncillo }\end{array}$ & cura de La Aceñuela \\
\hline $1493(8-5)$ & Juan Pérez del & cura de EI Robledillo \\
\hline
\end{tabular}

${ }^{51}$ Ibidem, f. 90r.

${ }^{52}$ Fuente: Ibidem, passim. 


\begin{tabular}{|c|c|c|}
\hline $\begin{array}{l}\text { AÑO (fecha } \\
\text { elección) }\end{array}$ & $A B A D$ & OFICIO CLERICAL \\
\hline & Castillo & \\
\hline $1494(14-5)$ & Luis García & cura de Las Pedroñeras \\
\hline $1495(5-5)$ & $\begin{array}{l}\text { Pedro Sánchez } \\
\text { de Zorita } \\
\text { Alonso Jiménez } \\
\text { (figura en abril- } \\
\text { 1496) }\end{array}$ & $\begin{array}{l}\text { cura de El Pedernoso } \\
\text { cura de Hontanaya }\end{array}$ \\
\hline $1496(17-5)$ & Juan Guerrero & chantre de Belmonte \\
\hline $1497(9-5)$ & Pedro Álvarez & cura de Tresjuncos \\
\hline $1498(9-5)$ & $\begin{array}{l}\text { Garcí Fernández } \\
\text { de Villanueva }\end{array}$ & cura de La Puebla \\
\hline $1499(14-5)$ & Alonso Díaz & canónigo de Belmonte \\
\hline $1500(20-5)$ & $\begin{array}{l}\text { Juan Sánchez de } \\
\text { la Cana }\end{array}$ & $\begin{array}{l}\text { beneficiado de Hontanaya y } \\
\text { canónigo de Belmonte }\end{array}$ \\
\hline $1501(26-5)$ & Diego García & cura de La Aceñuela \\
\hline $1502(1-6)$ & $\begin{array}{l}\text { Juan Pérez del } \\
\text { Castillo }\end{array}$ & cura del Robledillo \\
\hline $1503(29-5)$ & Andrés Jiménez & cura del Hinojoso \\
\hline $1504(22-5)$ & Pedro de Alarcón & cura de Hontanaya \\
\hline $1505(7-5)$ & Pedro Álvarez & cura de Tresjuncos \\
\hline 1506 & Juan Guerrero & chantre de Belmonte \\
\hline 1507 & \multicolumn{2}{|c|}{ Se aplazó la elección por cuestiones imprevistas } \\
\hline $1508(15-1)$ & $\begin{array}{l}\text { Juan Díaz de } \\
\text { Baños }\end{array}$ & canónigo de Belmonte \\
\hline $1509(23-3)$ & $\begin{array}{l}\text { Juan Hernández } \\
\text { de Guadalajara }\end{array}$ & cura de Robledillo, canónigo \\
\hline $1510(23-9-1509)$ & Andrés Jiménez & cura del Hinojoso \\
\hline $1511(20-12-1510)$ & $\begin{array}{l}\text { Pedro de Alarcón } \\
\text { (cede el puesto } \\
\text { a:) } \\
\text { Juan Hernández } \\
\text { de Guadalajara }\end{array}$ & $\begin{array}{l}\text { cura de Hontanaya } \\
\text { cura de Robledillo, canónigo }\end{array}$ \\
\hline $1512(13-9-1511)$ & $\begin{array}{l}\text { Gregorio de } \\
\text { Sacedón }\end{array}$ & cura de Villaescusa de Haro \\
\hline $1513(25-10-1512)$ & Pedro de la Zarza & beneficiado de Hontanaya \\
\hline $1514(5-9)$ & Garcí Fernández & cura de La Puebla \\
\hline $1515(4-9)$ & $\begin{array}{l}\text { Juan Díaz de } \\
\text { Baños }\end{array}$ & canónigo de Belmonte \\
\hline $1516(10-9)$ & $\begin{array}{l}\text { Juan Hernández } \\
\text { de Guadalajara. }\end{array}$ & cura de Robledillo, canónigo \\
\hline $1517(1-9)$ & Andrés Jiménez & cura del Hinojoso \\
\hline $1518(13-9)$ & Gregorio Osorio & beneficiado de Hontanaya. \\
\hline
\end{tabular}


Ya en la siguiente jornada, el martes, y probablemente tras la misa matinal, se procedía a tratar los asuntos económicos: se firmaban, renovaban o revocaban diversos contratos de arrendamiento; los clérigos llevaban o declaraban lo recaudado en concepto de diezmo de cereal; y el abad saliente hacía exposición de cuentas, tanto los descargos por cobro de rentas (censos, diezmos), como los cargos por gastos diversos, casi siempre de administración y de liturgia. Después el mismo abad saliente cobraba sus derechos específicos ya citados y hacía el reparto de las raciones correspondientes a los hermanos que hubieran respondido a los requisitos.

Tras la comida -esta vez costeada con cargo a los fondos del cabildo-, los cofrades rezaban en la mesa una memoria fúnebre por el alma de los benefactores que donaron bienes o rentas a la abadía en sus mandas testamentarias. Seguidamente, esa tarde salían camino de la iglesia del pueblo entonando el salmo "Miserere mei Deus" y ya en el templo rezaban un responso por Santa María y la persona de la advocación de la misma iglesia. ${ }^{53}$

El hecho de que estos actos se encuentren detallados en las actas y en las ordenanzas no significa que todos los puntos que se han señalado tuvieran que tener lugar a fortiori, ni que se realizaran en mismo orden estricto. De hecho, algunas veces la toma de posesión del nuevo abad tuvo lugar con posterioridad a la de los nuevos cofrades, e incluso parece que este cambio se consolida en la segunda mitad del siglo XV, ya que se juzgaría más razonable que los nuevos miembros contribuyeran a la elección del nuevo director. Asimismo, con todo pragmatismo se estableció que el cobro de las raciones por parte de los cofrades se efectuase en la última reunión. Pero en todo caso pocas variaciones se advierten con relación a lo expuesto.

También la fecha de la junta fue cambiando con el paso del tiempo. En torno a 1420 estaba establecido que se realizara el martes posterior a Todos los Santos, pero medio siglo después se hace hacia mediados de abril, y ya después de 1510 en una época de muchas irregularidades, la junta pasa a celebrarse en los primeros días de septiembre, lo que se acaba concretando en 1517 en una ordenanza que determina que sea el primer domingo de septiembre cuando se deba realizar la junta "por razon que mejor sean acompañados de la jente del pueblo". ${ }^{54}$ Pero pese a los vaivenes en los días fijados para la

53 Ibidem, f. 87r.

$54 \mathrm{Ibidem}, \mathrm{f} .48 \mathrm{v}$. Las irregularidades tuvieron un año clave en 1511, en que muchos componentes se encuentran excomulgados, y por ello los clérigos 
celebración de la reunión y los rituales, el hecho de que los clérigos se reúnan en fechas preestablecidas obedece a que era difícil que estuvieran en continuo contacto dada su residencia dispersa, problema de que no se adolecía en la ciudad de Alcaraz.

Durante los días en que transcurrían las reuniones y ceremonias, el aposentamiento de los cofrades era procurado por los clérigos del pueblo en que pernoctaban. Por otra parte, las reuniones solían hacerse en la iglesia parroquial del pueblo elegido para la ocasión, aunque a veces también en la vivienda del abad de turno o incluso en la de algún vecino hacendado que tenía intención de cerrar algún trato con los clérigos. Hemos de entender que al menos los banquetes tendrían lugar en estas casas y no en los edificios parroquiales. En cualquier caso, las comidas y cenas del cabildo estuvieron minuciosamente reguladas, tanto en el menú como en otros aspectos, como se advierte en una ordenanza de $1495 .^{55}$

Pero aparte de la vertiente lucrativa y más o menos lúdica, el cabildo se obligaba también a practicar la caridad, al menos una vez al año. Por ello, cuando se reunían los hermanos, el cura del lugar tenía que tener elaborado un listado con los pobres del pueblo que estuvieran en el hospital o recogidos por particulares, para invitarlos a una comida el segundo día de la junta. Al fin y al cabo, las cofradías contemplaban este piadoso objetivo que, dicho sea de paso, no siempre se cumplía.

Financiación. Bienes y rentas.

El cabildo de Tresjuncos se financiaba fundamentalmente con las rentas obtenidas de los bienes inmuebles que diversos particulares le habían ido donando. Estas rentas consistían en la renta que se aplicaba a los bienes inmuebles más el diezmo íntegro de la producción obtenida

del cabildo deciden hacer los oficios y las misas de ese año en sus respectivas iglesias y no conjuntamente.

55 "Iten ordenaron que den de comer a los señores del dicho cabildo a las çenas capones buenos o gallinas con cabrito. E al comer su adobado de carnero e piernas cosidas e cabrito al principio, o sy se diere arroz que non se haya adobado, e a las dichas çenas non den aves, saluo a los dichos señores; e a los huespedes les pongan otra mesa e les den cabrito e carnero para complimiento. E que den entre quatro vn capon, e entre tres vna gallina, e entre quatro vn quartillo de cabrito, e que el abat mayor tenga para su seruiçio el dia del ayuntamiento quatro seruidores e dos cosineros o cozineras, e otrosi ordenaron que en cada un año se eligia un prior segund costumbre antigua para que vea el seruiçio de la mesa e comida de los dichos señores. Eligieron por prior a Diego Garçia para el año venidero". Ibidem, f. 25r. Esta norma se derogó dos años más tarde en lo referente al consumo de aves, que quedará prohibido. 
en las propiedades agrarias, que no tributaban de igual manera que los demás bienes raíces. En este caso, los beneficiados se encargaban de recaudar el diezmo en las tierras de sus respectivos pueblos y los llevaban cobrados para repartirlos como parte de las raciones de los cofrades.

Al objeto de facilitar la gestión de las rentas, se estableció que cada clérigo tasara su respectivo beneficio y se hiciese responsable de las propiedades inmuebles que el cabildo poseía dentro de sus respectivas demarcaciones parroquiales. A los clérigos se les encomendaba que las sacaran a subasta sometiéndolas en general a arrendamiento en forma de censo enfitéutico no redimible por una o dos vidas. Los contratantes muchas veces eran ricos propietarios (Miguel Chillón, Alejo de Herriega y Juan del Algaba, vecinos de Monreal; un criado de la marquesa de Villena llamado Álvaro y residente en Belmonte en $1474 \ldots)$; otras veces, aquellas en que no existía un arrendatario disponible, eran los propios clérigos quienes se quedaban temporalmente con la propiedad rústica.

En los contratos se advierten asimismo relaciones clientelares entre el clero comarcal y otras instancias eclesiásticas. Por un lado, el arcipreste de Alarcón hizo ciertos servicios al cabildo y en 1481 el cura de El Pedernoso, su pariente Gonzalo de Iniesta, recibió de sus compañeros de cabildo noventa maravedíes que se le descontaron de la renta de una finca que ese año él arrendó en el pueblo en que oficiaba. ${ }^{56}$ Por otra parte Juan del Algaba, vecino de Monreal con el que el cabildo cerró varios contratos, era a su vez criado del bachiller Francisco de Molina, cura de su pueblo, cofrade de Tresjuncos (1474-1486), racionero en la Catedral de Cuenca y hasta vicario del obispado (1474-1475).

A fines del siglo XIV ya se cifraba en varias decenas el volumen de fincas rústicas que los cofrades poseían, cantidad que fue creciendo en las décadas posteriores, lo que convirtió al cabildo en un importante propietario de la región. Este hecho lo pondría en el punto de mira de otras instituciones que quisieron obtener provecho de tal circunstancia, como sucede con la iglesia colegial de Belmonte.

La nómina de propiedades agrarias se completaba con el usufructo de molinos en el río Záncara y cauces afluentes (La Angostura, El Saz) más un puñado de casas en la villa de Belmonte, que servirían de excusa a los clérigos de la colegiata de esta villa para entrar a participar en la hermandad de Tresjuncos. Por otra parte, tampoco en Tresjuncos los cofrades tuvieron su sede en una construcción específica, por lo que

${ }^{56}$ Ibidem, f. 14 r. 
cuando las fuentes aluden a la abadía, no se trata de una edificación sino únicamente del propio cabildo.

Como complemento a sus ingresos, la cofradía estableció una renta adicional basada en la recaudación de las penas monetarias a las que se condenaba a los propios miembros del cabildo por sus infracciones contra las ordenanzas. Esta renta se arrendaba, aunque serían los propios componentes quienes pujarían por ella.

Por último, existieron benefactores del cabildo que simplemente requerían los servicios de sus componentes para que estuvieran presentes en determinados oficios y misas pro anima, para lo cual donaban unas cantidades fijas en metálico al cuerpo de clérigos, pero no les legaban ninguna propiedad o renta. Un caso de esta naturaleza es el de Rodrigo Rodríguez de Avilés, señor de Martín Ovieco, quien en 1417 dispone en su testamento "que sean llamados los cabildos de Tresjuncos $y$ de Alcañabate" para contribuir a oficiar en sus ulteriores exequias; por lo que además cabe pensar que en El Cañavate también existiera otro cabildo de similares características, que, no obstante, no prosperaría. ${ }^{57}$

Conflictos con la colegiata de Belmonte.

En 1459 se fundó en Belmonte la iglesia colegial de San Bartolomé sobre la antigua parroquia por iniciativa del marqués de Villena don Juan Pacheco. De acuerdo con la bula de erección, la colegiata -que en buena medida es otra cofradía de eclesiásticos- debía ir financiándose con distintos beneficios y préstamos tomados de parroquias pertenecientes al marquesado de Villena y repartidas entre las diócesis de Cuenca y Cartagena, aunque finalmente sólo se anexaron beneficios de la parte conquense ( $\mathrm{y}$, contra lo establecido, también de Villarrobledo, en el obispado de Toledo). ${ }^{58}$ Pero a finales del cuatrocientos la iglesia de Belmonte decidió incorporar a sus arcas dos raciones de la abadía de Tresjuncos. Para hacerlo posible dos clérigos de la colegiata —el chantre Juan Guerrero y el canónigo Juan Sánchez de Baños- ingresaron en la abadía "para gosar de los reditos e rentas del dicho cabildo" pese a no ser beneficiados de ninguna de las iglesias vinculadas a la abadía, lo que suponía un insólito giro en la financiación de la colegial, que sólo contemplaba la incorporación de rentas estrictamente parroquiales, y una anomalía en el funcionamiento del cabildo de Tresjuncos. La anexión se

57 También requerirá la presencia de los frailes de San Agustín del Castillo. Biblioteca de la Real Academia de la Historia: Salazar M-46, ff. 151r152 r.

58 Ayllón Gutiérrez, C. 2008. "Iglesia y poder en el marquesado de Villena. Los orígenes de la colegiata de Belmonte". Hispania Sacra 60 (121): 118-119. 
formalizó el 24 de mayo de 1492. En ese momento el abad del cabildo era Juan de la Cana, beneficiado de Hontanaya pero también canónigo en la colegial, circunstancia que sin duda favoreció la entrada de los de Belmonte en la abadía. En esa ocasión los clérigos realizaron la junta anual ordinaria en Belmonte, en la que lo más importante fue la recepción, después de la comida, de los citados colegiales como nuevos cofrades. ${ }^{59}$

Los clérigos de Tresjuncos admitieron sin duda a regañadientes este ingreso, y desde entonces y pese a que la intromisión ya se había culminado, decidieron blindarse a fin de evitar que se agregaran nuevos clérigos de Belmonte y quedar así bajo control de la colegiata. Por ello se estableció que en el futuro ningún otro componente de ésta se integrara en la abadía. Pese a la aprobación de esta cláusula, algunos miembros del cabildo protestaron por la incorporación y por la actitud de los de Belmonte, alegando que su ingreso perjudicaba los intereses de la cofradía, de la que se llevaban cómodamente raciones de setecientos maravedíes a su casa. Por si ello fuera poco, el notario del cabildo había fallecido y se decidió que fuera sustituido por el chantre Guerrero, con lo que este clérigo intruso ampliaba su volumen de ingresos procedentes de la abadía. ${ }^{60}$

En consecuencia, el cabildo de Tresjuncos requirió a Pedro de Costa - recientemente ascendido a provisor del obispado de Cuencaque revocase y no diese aprobación a la supuesta intromisión de la colegiata en la abadía. Llegados a este punto, las circunstancias podían inclinarse a favor de la abadía de Tresjuncos, pues por entonces la Catedral de Cuenca se hallaba en una larga disputa con la iglesia de Belmonte. Costa emitió un mandamiento para que los clérigos de San Bartolomé no fueran admitidos, pero la colegiata replicó con la escritura en que se demostraba que la propia abadía había admitido la anexión y recibido a los colegiales, como se ha señalado. Avanzado el año de 1493 y tras consultar con Ruy Gómez de Anaya, abad de Santiago y "benefiçiado de la yglesia de Villiscusa, que cabe en la dicha abbadia", el provisor se vio obligado a conminar a los de Tresjuncos bajo amenaza de excomunión a aceptar la presencia de los dos clérigos de Belmonte. ${ }^{61}$

59 Archivo Parroquial de Belmonte: Caja siglos XV-XVI, s. $\mathrm{n}^{\circ}$ (Belmonte, 24-mayo-1492; Belmonte, 2-agosto-1493).

60 Libro del cabildo de Tresjuncos, ff. 16v-18r.

61 Para asegurar la situación, los integrantes de la colegial de San Bartolomé harán sacar traslado de la recepción que el año anterior se hizo de sus beneficiados por parte del cabildo de Tresjuncos. Archivo Parroquial de Belmonte: Caja de censos, s.nº. (s.f.) 
Pero este conflicto se vio también ligado a las citadas inasistencias a las juntas anuales del cabildo. De hecho, en 1500 Juan de la Cana se vio obligado a abandonar la cofradía en dudosas circunstancias siendo abad él mismo. En realidad se diría que el caso va asociado al hecho de que los de Belmonte no acudían al cabildo, por lo que en 1502 compareció el prior de la colegiata a una reunión en que se trató la cuestión de las ausencias de los clérigos de la colegiata que no asistían a la junta de Tresjuncos - ynpedidos por alguna sentençia de excomunion o suspension o destierro del perlado o señor de la tierra o çitados por Roma o para fuera del obispado-, por lo que se acordó que en tales casos pudieran ser sustituidos por otros colegiados de Belmonte. $^{62}$

La verdad es que la cofradía comarcal de Tresjuncos debió de ser la entidad que más acusara la erección de la colegial en la vecina villa de Belmonte, dado el volumen de rentas que ésta pasó a recibir de la zona. A la postre la hermandad se vio fagocitada por la iglesia de Belmonte, que con el apoyo de la casa señorial se había convertido en una suerte de catedral en la comarca.

\section{CONCLUSIÓN}

A la vista de lo desgranado hasta aquí, podemos realizar un balance acerca de las diferentes cofradías de clérigos seculares creadas en el área sureste de la Meseta castellana a lo largo de la baja Edad Media, a partir del análisis de dos casos que determinaron la vida eclesiástica, social y económica de sus respectivas comarcas y que hasta ahora no habían sido objeto de estudio: los cabildos de Alcaraz y Tresjuncos.

Estas cofradías y otras análogas presentan unas características que las diferencian entre sí. En función de sus circunstancias fundacionales, unas se crean en los tiempos de la conquista como factor de organización del nuevo clero parroquial (Alcaraz), otras esperan a tiempos ulteriores para configurarse (Tresjuncos). En este sentido se diría que sólo las grandes poblaciones vieron nacer pronto y por iniciativa real o episcopal a estas hermandades, mientras que en núcleos más modestos fueron los propios clérigos quienes decidieron con posterioridad unirse en este tipo de organizaciones. De acuerdo con la categoría de sus integrantes, en ciertos cabildos participan beneficiados parroquiales junto con capellanes de sus iglesias, mientras otros sólo engloban uno de dichos estratos, existiendo un tercer grupo de naturaleza mixta en donde los clérigos conviven con seglares. También existen diferencias en cuanto al ámbito geográfico de acción, por lo que

\footnotetext{
${ }^{62}$ Libro del cabildo de Tresjuncos, f. 31r-v.
} 
si la mayoría de las hermandades tiene carácter local (Alcaraz), otras menos comunes abarcan varios pueblos de una misma comarca (Tresjuncos).

Pese a las diferencias, existe una coincidencia entre los dos cabildos a la hora de fijarse sus objetivos fundamentales, los cuales orbitaban en torno a la defensa de los intereses de los clérigos, es decir, de sus privilegios de ordo, sus prebendas y derechos, y al compromiso de sus miembros de ofrecerse apoyo mutuo, un auxilio que tenía una vertiente espiritual en virtud de los oficios celebrados tanto en vida de los componentes como tras su muerte. Sin embargo, las manifestaciones de caridad propias de estas cofradías fueron esporádicas en Tresjuncos y nulas en Alcaraz.

Otro elemento común a ambas cofradías se halla en la manera en que sus propios miembros las designan, que es con el término cabildo, si bien en Tresjuncos a veces también se emplea el de abadía. Asimismo, en ambos casos al director se le denomina abad, la duración de su mandato es de un año, dirige las reuniones y se encarga de coordinar la gestión económica distribuyendo las raciones a sus compañeros.

Las cofradías no acogían indistintamente a todos los clérigos de su demarcación respectiva, sino sólo a aquéllos que cumplían la residencia en la población en que se hallaban sus oficios. Esto limitó la composición de estas hermandades, que en consecuencia se convirtieron en grupos que se distinguían del resto del clero local o comarcal. Este carácter selecto de sus miembros se intensificó en la medida en que entre ellos abundaron los curas sobre los beneficiados simples y contribuyó a que los cofrades, aprovechando su prestigio, estrecharan sus vínculos personales y materiales con los clanes más influyentes de su entorno, que eran los más idóneos para instituir memorias, afianzando de este modo su influencia sobre la sociedad local. Erigidas, pues, en grupos de poder, estas hermandades se encargaron de participar en ceremonias públicas solemnes y de organizar exequias fúnebres y aniversarios de la oligarquía.

Para cumplir con sus objetivos las dos cofradías establecieron con evidente fortuna un sistema de acaparamiento de numerosos bienes (dinero en metálico, fincas rústicas y urbanas) y rentas (censos enfitéuticos, alquileres) procedentes de las donaciones piadosas de vecinos ("bienhechores") que a cambio establecian memorias funerarias. Al tratarse de clérigos, los cofrades dispusieron de las consabidas pautas de coacción psicológica para influir sobre los convecinos, captando de este modo las mencionadas donaciones como complemento a sus beneficios (o derechos de capellanía) y con ello cubrían sus apetencias materiales. Con sus ingresos financiaban los oficios y misas pro anima 
defunctis que asegurasen a los benefactores la vida eterna en el mundo de la contemplación divina y en el terrenal la exhibición de su poder ante los vecinos. Además el ritual fúnebre se convirtió en una técnica de retroalimentación por cuanto los fieles asistentes a los oficios funerarios quedarían dispuestos a aumentar con sus aportaciones ulteriores todo este entramado piadoso-económico.

Pero los cofrades establecieron otras estrategias adicionales de financiación. Por un lado, en Alcaraz fue muy habitual la atracción de fondos de capital que eran invertidos como censos consignativos a modo de créditos facilitados a campesinos necesitados que a su vez pagaban un canon periódicamente, de manera que se generaba una fuente perpetua de recaudación para los clérigos. Esta práctica se combinaba con simples arrendamientos vitalicios, fórmula mucho más empleada en Tresjuncos. Asimismo se observa una tendencia en este cabildo a cerrar tratos con una serie más o menos constante de ricos hacendados, mientras que los clérigos de Alcaraz no parece que consoliden clientelas fijas entre sus convecinos.

Por otra parte, como las propiedades de los cabildos de clérigos no estaban gravadas con el diezmo diocesano ni segregaban tercias reales, todo lo diezmado en sus tierras iba íntegramente a parar a sus componentes. Éstos además cedían con harta frecuencia a la cofradía en general por vía testamentaria - una parte o el total de su fortuna, de modo que una porción de la riqueza que los capitulares habían obtenido por el cobro de sus raciones revertía de nuevo en la hermandad para destinarse a la compra de nuevos bienes y censos con que seguir autofinanciándose. $\mathrm{Y}$ a todo ello cabe añadir que ni en Alcaraz ni en Tresjuncos los clérigos tuvieron una sede material ad hoc, lo que les suponía un ahorro económico: les bastaba utilizar para sus reuniones los edificios parroquiales y sus propias viviendas, una eficaz táctica de gestión material.

Los asociados consiguieron un importante grado de influencia sobre otros eclesiásticos no partícipes en la corporación, dado que les aseguraban en muchas ocasiones préstamos o buenas viviendas que eran propiedad del cabildo, aparte de las que los propios cofrades obtenían para sí. Por tanto, los miembros de las hermandades no sólo colaboraban solidariamente entre sí y se apoyaban en el grupo para su propio provecho, sino que extendieron su influencia sobre la sociedad circundante y en particular sobre los demás eclesiásticos, que se convirtieron en contratantes preferenciales en los negocios de las cofradías clericales, incluso en el ámbito de la especulación agraria.

Mediante todos estos procedimientos, los cabildos de clérigos de Alcaraz y de Tresjuncos llegaron a atesorar grandes patrimonios dada la 
actividad acusadamente especulativa de sus miembros. Esta circunstancia conllevó la consolidación de las hermandades clericales, pero también el que a finales del siglo XV las rentas de la abadía de Tresjuncos pasaran a ser objeto de ambiciones externas y de conflictos intraeclesiales. Sin embargo, la alta rentabilidad de las raciones de sus cofrades, unida a la obligatoriedad de guardar la residencia sirvieron para evitar el absentismo clerical en la comarca, que por ello fue muy inferior al de otras zonas colindantes.

En definitiva, las cofradías de clérigos seculares locales y comarcales del sureste castellano constituyeron una suerte de sindicatos de privilegiados, a la manera de cabildos autónomos, cerrados y dotados de prerrogativas. Sus componentes reproducían un acusado espíritu corporativo al salvaguardar sus derechos e intereses frente al poder civil y la jerarquía eclesiástica. En tal sentido, estas hermandades funcionaron a veces en forma de contrapoder dentro de la estructura eclesial frente a las disposiciones que los obispos hicieran llegar a través de sus vicarios y arciprestes. En cuanto a sus dinámicas particulares, la cofradía de Alcaraz gozó de cierta autonomía, posición económica y libertad de movimientos, mientras que la de Tresjuncos se vio enredada en la vorágine que supuso la expansión económico-financiera de la vecina colegiata de Belmonte. No obstante ambas cofradías lograron subsistir a lo largo de toda la Edad Moderna.

Una última consecuencia del establecimiento de estas cofradías en el ámbito rural fue el desvío hacia los clérigos de unas rentas que de otro modo podrían haber revertido en la financiación de la obra y fábrica de las iglesias rurales, tan necesitadas de liquidez en estos pueblos. Pero los beneficiados prefirieron desarrollar sus rituales al margen de las parroquias en las que servían (aunque se aprovecharan del uso de sus templos), captando así donaciones y rentas a fin de celebrar memorias funerarias que de no haber existido cabildos lo más probable es que se hubieran derivado a las parroquias. Este desvío de capital en claro perjuicio de unas entidades eclesiásticas sobre otras delata una de las contradicciones del propio sistema de mantenimiento material de la Iglesia.

\section{APÉNDICE DOCUMENTAL}

1420, noviembre 9. Tresjuncos.

Ordenanzas del cabildo de Tresjuncos. 
Archivo Parroquial de Las Pedroñeras (Cuenca): C 15, C-3, ff. 85 y SS.

Santi Spiritus ad sit nobis gratia. Amen.

En el nombre de Dios en todopoderoso criador de todas las cosas e a honor e alabança de la Virgen bienaventurada Santa Maria, Nuestra Sennora, e de Todos los Santos de la corte çelestial. En nueue dias de nouiembre, anno de la Natiuidat del Nuestro Sennor lesu Christo de mill e quatroçientos e veynte annos. Este dia estando juntados en Tresjuncos, en la yglesia de Santo Domingo, perrochia del dicho lugar, los onrados Johan Sanches, clerigo de Tresjuncos, abat mayor del cabillo de Tresjuncos, e Juan Ruis, bachiller en Decretos, vicario de Belmonte, e Domingo Ferrandes, clerigo de Montreal, e Ruy Sanches, clerigo del Finojoso, e Apariçio Martines, clerigo de la Ossa, e Miguel Sanches e Anton Sanches, clerigos de Fuente Anaya, e Juan Martines, clerigo del Pedernoso, e otros clerigos del dicho cabillo, todos mouidos con buen proposito e con entençion de reformar munchas cosas que estauan menguadas en el dicho cabillo, asy çerca de lo espiritual commo en lo tenporal; e a fyn que el seruiçio de Dios e de la su Iglesia fuese e sea acresçentado, e el pueblo acreçentase en buena deuoçion; e las animas de los bien fechores del dicho cabillo, por los sacrifiçios, oraçiones e obras pias fuesen libradas de las penas del Purgatorio, e los clerigos benefiçiados que al tiempo seran en el dicho cabillo biuan onestamente e en buena pas e amorio e caridat, ordenaron estas ordenaçiones que se syguen:

Primeramente, el dicho sennor abat e clerigos, todos unanimiter e en concordia, considerando que poco aprouecha faser ordenaçiones sy non son guardadas, o aya alguna presona que las faga guardar. Por ende todos de su libre voluntad se sometieron de ser obedientes a los mandamientos e llamamientos del abat mayor que por tiempo sera en el dicho cabillo. Esto se prometyeron por sy e sus sucçesores, assy estando juntos en uno en cabillo, como fuera de cabildo./

Yten se sometieron e prometieron de ser obedientes al dicho abat mayor en todas las penas que en estas ordenationes se contienen, e de las pagar llanamente; e qualquier que fuere rebelde e non quisiere pagar las dichas penas en que cayere fasta nueue dias despues que el dicho abad ge los mandare pagar, que pague tres florines al cabillo, e que desta pena non pueda faser remissyon alguna el dicho abad. Enpero sy tanta obediençia e arrepentimiento ouiere en el que non obedesçio los dichos mandamientos del abat, que el pueda remityr la pena del tiempo de los otros annos, mas non de los dyneros e que sienpre los pague. Enpero sy legitima escusaçion dieren al dicho abat, que sea releuado de la dicha pena. 
Iten ordenaron que qualquiera clerigo que fuere monido por el abat o por el prior para el sex o para ofiçios quales quier e non vyniere, peche veynte marauedis sy non diere escusaçion legitima.

Iten ordenaron que todos los clerigos que vynieren al seys, que vengan a lo menos a las missas, so pena de veynte maravedis, e sy estouieren en el lugar e non estouieren presentes a la missa mayor, que non le den pytança, saluo sy ouiere escusaçion legitima.

Yten ordenaron que el clerigo que non lleuare sobrepellis a cabillo, que pague de pena tres maravedis. I

Yten ordenaron que qualquier que non çelebrare que pague quatro maravedis, saluo sy ouiere liçençia del abat.

Yten ordenaron que sy algund clerigo finare, que todos sean tenidos los çinco clerigos mas çercanos que para esto fueren llamados por el abat o piostre de venir luego a lo vannar e a lo vestir e enterrar e le faser sus ofiçios conplidamente e vigilia de nueue liçiones e letania; e que les den de comer e çebada de lo del difunto; e sy fuere menesteroso que lo cunplan del cabillo. E dende que lo faga saber a todo el cabildo fasta nueue dias e que le vengan a faser todo su conplimiento segund es acostumbrado por el cabillo. E el que para esto fuere llamado e non viniere que peche de pena quarenta maravedis para la mesa del cabillo, e que desto non sea fecha remision alguna. E que los clerigos que vynieren a los nueue dias que ayan de pytança çiento e çinquenta maravedis, e que les den de comer e çebada de lo del cabillo commo desuso es dicho.

Otrosy ordenaron que sy algund clerigo del dicho cabillo touiere quexo de otro clerigo del dicho cabillo, que lo llame para ante el abat mayor fasta en preçio de çient maravedis; e el que fuere llamado que sea tenido de paresçer so pena de dies e seys maravedis, e que el abad que lo libre amigablemente, e que ninguno non sea osado de contradesir su sentençia, so pena de treynta maravedis. /

Otrosi, qualquier clerigo que en el sex o en algund cabillo o ayuntamiento jugare los dados con otra qualquier presona, peche veynte maravedis.

Otrosi, qualquier clerigo que denostare injuriando a otro estando a la mesa o lo desmintiere o fiçiere burla o cosa desonesta, peche çinco maravedis por cada ves. 
Iten ordenaron que ninguno estando a la mesa non leuante disputaçiones nin questiones e sy alguno las leuantare e les mandares el abat por terçera moniçion que callen e non le obedesçieren, que pague el rebelde dies maravedis, e que luego sea fecha execuçion.

Otrosy ordenaron que ninguno non sea osado de lleuar mas de vn santchristan o vn conpannero con el. Sacado sy fuere tal presona, que el abat entienda que los deua lleuar, mas quede a su deliberaçion.

Otrosy ordenaron que qualquier que conbidare alguno para comer en cabillo syn liçençia del abad, peche dies maravedis.

Otrosy que qualquier que a la mesa departiere despues que el abat mayor pusiere silençio, peche dos maravedis.

Otrosy qualquier que rogare por qualquier de los que cayeren en pena, peche por cada ves que rogare çinco maravedis.

Otrosy ningund clerigo non sea osado de beuer ante de yantar, e dicha la misa mayor nin el abat nin el prior non le puedan dar liçençia por esto, sy non fuere medio açumbre de vyno para el prior e a vn compannero que le ayude a coçinar, so pena de çinco maravedis. I

Otrosy ordenaron que el martes primero despues de Todos Santos se faga el sex, e que vengan los clerigos mas çercanos el lunes en la noche a la vigilia e que sean el martes todos a las misas e el abad mayor que envie con tiempo a monirlos.

Otrosy sy el abat mayor non fisiere el sex al tiempo suso dicho, pague çinco florines para la mesa del cabillo, e los que non vynieren al sex non auiendo escusaçion legitima, peche cada uno un floryn para la mesa del cabillo.

Otrosy ordenaron que quando acabaren de comer, que fagan ençima de la mesa memoria por todos lo cofadres del cabillo, primero por los biuos e despues por los defuntos e por todos aquellos que fisieron mandas al cabillo, e quando vayan a la iglesia que digan el salmo de "Miserere mey Deus" de dos en dos. E quando seran en la iglesia, digan vn responso de Santa Maria con oraçion suya e de la vocaçion de la iglesia e fagan collaçion.

Iten que sy el abat mayor quisiere veer alguna cosa con los clerigos e les mandare que esten ende que ninguno non se vaya syn liçençia del abat mayor so pena de çinco maravedis. 
Iten que en el proponer de los negoçios que non fable ninguno fasta que el que propusiere aya acabado e sy por el abat le fuere mandado que calle por terçera moniçion e non lo fisiere que pague veynte maravedis.

Otrsy mandaron que ese dia traygan todos sus tasaçiones de sus benefiçios por menudo e por granado e sy non el cabillo lo tasara segund a el bien visto sera, e que la trayga de cada anno con juramento.

Otrosy ordenaron que todos los clerigos curas del dicho cabillo, que cada vno en su lugar arriende o faga arrendar las posesiones del cabildo en su lugar poniendose por / almoneda publica mente nueue dias con escriuano publico e que las trançen en aquella presona o presonas que mas dieren por ellas tomando buen recabdo e buen fiador, e que se fagan las rentas de las vynas o de otras cosas que se pertenesçen arrendar a dineros e las faças que se arrienden a pan o a dineros commo mejor pudieren. E el abat mayor que vaya a requeryr a cada lugar en que forma estan arrendadas las posesyones del dicho cabillo. E sy fallare que el clerigo o clerigos del dicho lugar an fecho algund enganno o ouieren puesto mal recabdo en las arrendar, que sean tenudos o tenudo al menoscabo que el abat fallare que esta fecha otrosi a la penitençia que al cabillo les quisiere echar e fuere su merçed. E el abat mayor sea tenudo cada anno de yr a visitar las posesiones; sy non, que peche en pena çinco florines de oro.

Otrosy que yendo el abad mayor a uisitar las dichas posesiones que por doquier que acaesçiere, que el clerigo o clerigos del dicho lugar sean tenudos e tenudo de lo faser toda onra e de le dar de comer de lo suyo e çebada para su mula mientra visitare. E que el abat mayor non despienda ninguna cosa de lo suyo.

Otrosy ordenaron que quando el abat mayor enbiare su carta para monir el cabillo, que doquier que la carta fuere enbiada que la enbien los clerigos en la forma que vieren que va ordenada de vn lugar a otro e qualquier que non la enbiare que peche en pena dies maravedis e que pague las pitanças de todos los que non vinieren por su fallesçimiento. $E$ que la carta que sea trayda al cabillo por que paresca la diligençia e que la trayga el postrimero clerigo.

Otrosy ordenaron que cada anno aya de pytança el que fuere abat mayor por su trabajo çiento e çinquenta maravedis de moneda blanca. /

Otrosy ordenaron el cabillo que ofrescan todos los clerigos sendas blancas, e los que non lo fisieren pechen dos maravedis, e desta pena den de pytança al clerigo que dixere la misa quatro maravedis e sendos 
maravedis para los que siruieren en el altar e que çelebre quien el abat mandare.

Otrosy lo que a de aver el prior es esto: lo menudo de todas las reses que matare menudas e el pellejo e vna colla de cada res sacada segund costumbre antigua.

Otrosy ordenaron que quando el abat mayor mandare prendar al prior o a otro qualquier clerigo o a qualquier de los cofadres clerigos 0 legos por qualquier cosa que deuan al dicho cabillo o penas en que ayan caydo qualquier clerigo o cofrade del dicho cabillo que la prenda defendiere, que pechen en pena çinco florines de oro e que pague los maravedis que deuie con el doblo, e la prenda que fuere tomada que la puedan vender fasta terçero dia a pro del cabillo e a dapno de cuya fue la prenda. E sy por esta rason se querellare a otro sennor nin çitare al abat o alguno de los del cabillo, que peche en pena vn comer e que le sea fecho reçefit quanto fuere merçed del cabillo.

Otrosy ordenaron los clerigos e el abat mayor que el dicho abat mayor pueda poner pena o penas pecuniarias por qualquier cosa que sea deuida al cabillo asy de pechos commo de otras cosas contra aquellas presonas que deuieren las cosas sobre dichas.

Otrosi ordenaron que, considerando en commo algunas cosas fallauan por costumbre e se vsaban en el sex e en los otros juntamentos en que paresçia que era mas seruiçio / de los ombres e vana gloria del mundo que non seruiçio de Dios, acordaron todos los suso dichos en nonbre e en bos de todo el cabillo e por que Dios sea mejor seruido e la deuoçion de los cofadres sea acresçentada en bien, e todas las otras gentes sean mouidas a deuoçion por faser sus ayudas e limosnas a los dichos clerigos del dicho cabillo, ordenaron esto que se sigue:

Primeramente, que la caridat que se solia faser en segundo dia del sex a los ricos que tienen en sus casas su pasada (¿posada?) que sea fecha a los pobres menesterosos, fijos de Dios, en esta manera: que el clerigo benefiçiado del lugar donde se fisiere el sex tenga por escripto para aquel dia todos los pobres del dicho lugar, e los que fueren fallados en el ospital o en otras casas de los buenos christianos que cojen por amor de Dios, que los conbiden, que coman en el cabillo o que les enbien sus raçiones, segund que viere el abat o el prior, que fuere guissado. E que non se de la dicha caridat segund se solie ante dar.

Otrosy ordenaron que todas las penas pecuniales sean puestas por renta en el almoneda el segundo dia del sex e lo que saliere e montare la renta sea del cabillo, e a aquel en quien quedare la renta de buen fiador al cabillo; e el arrendador acuse las penas en este libro 
contenidas delante el abat. E el abat judgue las dichas penas segund esta ordenado por las leyes e estatutos del dicho cabillo.

Otrosy ordenaron que el prior del dicho cabillo e otros de los cofrades en su nonbre por mandado del abat sea tenudo de prendar a todos aquellos que cayeren en estas penas puestas en este libro, e el que non quisiere dar prenda e la / defendiere al prior o a aquel que fuere en su nombre por mandado del abat, peche la pena doblada; e sy por aventura quisiere porfiar en su rebeldia, el abat enbie dos o tres o quattro de los cofrades, e los cofrades que el abat mandare sean tenudos de yr so pena de sendos florines a prendar al reuelde. E sy los non quisiere dar prenda, peche la pena del tres tanto e demas por los jornales a los que fueren, cada veynte maravedis e sy nesçesario sera todos los clerigos del cabillo sean monidos a su costa del reuelde a conplir de derecho al querelloso e pague la pena con el quatro doble.

Otrosy ordenaron que los quatro dias del sex que sean çelebradas las misas mayores con diacono e subdiacono, e qualquier abat que çelebrare misa mayor en el sex syn lo que dicho es, por cada vegada peche vn floryn.

Otrosy ordenaron que quando el abad mayor muniere para faser ofiçios en algund lugar por los finados que dexaron sus ayudas que vengan lunes en la noche o qualquier dia otro que el abad mandare que sean los clerigos mas çercanos a las vigilias non auiendo legitima escusaçion, e sy non viniere peche dies maravedis, e esta legitima escusaçion sea demandada conjura.

Otrosy ordenaron en esta ley suso dicha que se entienda que vengan a cada ofiçio que fisiere los clerigos mas çercanos tres dellos a la vigilia.

Otrosy ordenaron que el abat del dicho cabillo trayga este libro de los estatutos para que sea leydo en cada ayuntamiento de los clerigos del dicho cabillo fueren ayuntados e sy non lo traxiere peche cada ves vn floryn.

Otrosy ordenaron que cada que el abat mayor muniere a los clerigos, que el prior sean tenudo de venir / ende a conplir aquellas cosas que son de su ofiçio e por recabdo en lo que se deue guisar para los dichos cofadres, segund que es vso del cabillo, e sy non veniere non auiendo legitima escusaçion peche vn floryn.

Otrosy ordenaron que todos los que troxieren moços o santchristanes a cabillo que non sean casados o ordenados de orden 
sacra, que non se asyenten a la mesa mayor de los clerigos a comer mas que el prior les mande seruir e despues que coman con el.

Otrosy ordenaron que donde quier que el cabillo fisiere juntamento que sea vn clerigo leyendo aquel que el abat mandare, so pena de dies maravedis; e quando el abat pusiere silençio que todos lo tengan so pena de obediençia e de dos maravedis a cada vno que mouiere la conseja e el roydo.

Otrosy ordenaron que qualquier que fuere elegido por abat mayor por los clerigos del cabillo que sea tenido a lo seer e açeptarlo e el que lo contrario dixere que pague tres florines en pena e que sea otro elegido.

Otrosy ordenaron que cada vn clerigo benefiçiado en su lugar sea tenudo de aposentar los clerigos en sus posadas e sy non lo fisiere que peche al cabillo un ayantar con todo lo que fuere nesçesario.

Otrosy ordenaron que qualquier que fuere abad, que quando llamare a cabillo a los clerigos que sea tenido de tener recabdadas sus pitanças e sy non las touiere prestas para las dar que las pague de sus bienes propios. I

Otrosy ordenaron que el abat sea tenudo de faser cada anno cantar cabillo en los lugares todos del dicho cabillo so pena de çinco florines. E sy tal fuere el lugar que non ouiere renta para lo faser que junten dos lugares para faser un cabillo.

Otrosy ordenaron que qualquier que fuere abat sea tenudo de recabdar e aver las posesiones para el cabillo de aquellas presonas en quien estouieren enajenadas, e que en esto que ponga toda su diligençia, e que lo que ende gastare que lo cuente al cabillo; e que sy nesçesario sera que faga repartimiento en todos los clerigos del cabillo con consejo de dos clerigos e que lo que el repartiere que los dichos clerigos sean tenidos a ge lo dar al plaso que el mandare so pena de çinco florines.

Otrosy ordenaron que qualquier clerigo benefiçiado del dicho cabillo que quisiere ser cofadre deste dicho cabillo que sea tenido a dar de la entrada çinquenta maravedis e vna libra de çera para el dicho cabillo.

Iten ordenaron el abat mayor e clerigos del dicho cabillo de Tresjuncos que qualquier clerigo benefiçiado del dicho cabillo sea tenido e deuido a resçebyr sus decimas del pan que se cogiere en las tierras del dicho cabillo para darlo en cuenta de cada vn anno quando se ayuntaren los cabillos para que el dicho abad mayor faga raçion a cada vno de los 
clerigos que vynieren a cantar los cabildos. E qualquier clerigo que fuere remiso en lo asy non conplir que sea tenido por juramento que faga lo que podria rendir que lo pague de sus bienes al dicho cabillo para faser la dicha repartiçion e que cada vn clerigo sea tenido dar la cuenta de lo que asy ryndiere su lugar o lugares donde el abad mayor mandare e asygnare so pena de priuaçion de la pitança.

1508, junio 23. Alcaraz.

Ordenanza del cabildo de Alcaraz dando permiso a sus miembros a ausentarse de la ciudad a causa de la epidemia de peste, a cambio de perder una sexta parte de sus respectivas raciones.

ADA: ALZ 149, f. 76r-v.

(En el margen:) Ordenança que los que quisieren absentarse en tiempo de la pestilençia puedan perdiendo la sesta parte de sus raçiones.

En la çibdad de Alcaras, viernes veynte e tres dias del mes de junio, año del nasçimiento del Nuestro Señor lesuchristo de mill e quinientos e ocho años, dentro en el vistario de la yglesia de la Trinidad de la dicha çibdad, estando ayuntados los señores benefiçiados del cabildo de la dicha çibdad, estando en el dicho ayuntamiento el venerable señor [(tachado:) Gregorio] el bachiller Gregorio Calderon, clerigo cura de la yglesia de Santa Maria; e el bachiller Garçia de Grajal, clerigo cura de la yglesia de Sant Inasçio; e Lope Rodrigues, clerigo cura de la yglesia de San Pedro; Ferrand Gomes, clerigo beneficiado en la dicha yglesia de San Pedro, abad del dicho cabildo; e Agostin de Beteta, clerigo beneficiado en la dicha yglesia de Santa Maria; e Ferrando de Morales, clerigo cura de la yglesia de la Trinidad; e Martin Alonso, clerigo benefiçiado en la yglesia de Sant Inasçio, e en presençia de mi, Juan Gonzales de Viscaya, notario e escriuano del dicho cabildo. Los dichos señores estando ayuntados a cabildo segund que lo han de vso e de costumbre, hordenaron e mandaron que por rason que en esta çibdad se ha començado de morir de pestilençia e meren (sic), e crese que algunos de estos señores querran absentarse de ella por la dicha pestilençia, por ser enfermedad que se pega e de ello podrian falesçer, que hordenauan e mandauan que los que se quisiesen absentar de esta çibdad por el tiempo que estouieren absentes que non sean priuados de sus raçiones de la mesa capitular saluo que cada vno de los absentes pierdan la sesta parte de sus raçiones por el tiempo que esto seran absentes, e ganen las dichas sestas partes los que quedaren e estouieren presentes e esto vsando con los [(tachado:) pre] absentes de misiricordia e por que del todo non sean despojados los absentes / de todas sus raçiones segund la hordenança del dicho cabildo, lo qual hordenauan para agora e para siempre jamas, e asi lo mandaron asentar e lo firmaron de sus nombres 
de algunos de los dichos señores, eçebto los dichos señores el bachiller Calderon e Lope Rodrigues, que dixeron que lo contradesian asi commo curas de animas e que ellos querian estar presentes, e lo contradesian, saluo que lo pidiesen por justiçia los que se absentaren, e todos los otros señores benefiçiados suso dichos que aqui firmaron sus nombres dixeron que non enbargante su contradiçion de los suso dichos dos benefiçiados que ellos seyendo la mayor parte del dicho cabildo commo lo heran que representauan el cabildo que por rason que en muchas yglesias, catedrales e colegiales e otras vniversidades se vsaua e guardauan que los absentes por pestilençia non perdiesen saluo la sesta parte de la raçion del tiempo que absentes estouiesen, e porque esto les paresçiese conforme a caridad e derecho e rason que todavia hordenauan e mandaron que los que se absentaren por pestilençia agora e para siempre jamas pierda solamente la sesta parte de sus raçiones del tiempo que estouieren absentes e ganen la sesta parte los que estouieren presentes.

Fernand Gomes. Agustinus de Veteta. Ferrandus, cura. Martin Alonsus, bachalarius. Alonso Gonzales, notario.

1513, abril 30. Alcaraz.

Ordenanza del cabildo de beneficiados de Alcaraz por la cual se imponen sanciones por las ausencias de capitulares en las procesiones.

ADA: ALZ 149, f. 26v.

En postrimero dia del mes de abril de mill e quinientos e trese años, estando ayuntados los señores benifiçiados de la mesa capitular de esta çibdad de Alcaras, estando en el dicho ayuntamiento en la yglesia de Nuestra Señora Santa Maria, los reuerendos señores Lope Rodrigues, clerigo cura de la yglesia de San Pedro, e el bachiller Martin Alonso, benefiçiado en la yglesia de Sant Inasçio, e el bachiller Juan Remires, clerigo cura de la yglesia de San Miguell, abad del dicho cabildo, e Gonçalo Sanches de Siles, benefiçiado en la dicha yglesia de Sant Inasçio, e el bachiller Garçia Gonçales de Viscaya, clerigo benefiçiado en la dicha yglesia de Santa Maria, hordenaron e mandaron faser hordenança que por rason que en esta dicha çibdad ay costituçion e hordenança antigua del dicho cabildo de yr todos generalmente en las proçesyones generales e espeçiales e los otros votos que van fuera de esta çibdad, especialmente el dia de Señor San Pedro Martir a Señor San Saluador, e el primero dia de mayo a Nuestra Señora Santa Maria de Cortes. Por ende, que añadiendo en la dicha hordenança que mandauan e mandaron e hordenaron que de aqui adelante que todos los benefiçiados que agora son e fueren en esta dicha çibdad de oy en adelante, sean tenudos e obligados de yr en las dichas proçesyones 
personalmente, estando en la dicha çibdad e syn graue enfermedad, so pena de quatro reales castellanos por cada ves que dexaren de yr en las dichas proçesyones, los quales el abad del cabildo que es o fuere sea obligado a los cobrar del que non fuere e se los ponga por pagados en la raçion del tal benefiçiado, e los reparta entre todos los benefiçiados que fueren en las tales proçesyones, lo qual faga e cumpla so la pena contenida en las dichas hordenanças, quedando en su fuerça e vigor la hordenança antigua que fabla contra los que non van a las proçesyones, los quales dichos señores firmaron aqui sus nombres e la mandaron guardar so la pena del juramento que fecho tiene. Sea entendido esta dicha pena de los quatro reales en las dos proçesyones de San Saluador e Cortes; e en las otras proçesiones se guarda la pena del real.

Cura Beati Petri. El bachiller Estrada. Martinus Alfonsus bachallarius. El bachiller Ramires. Alfonsus Petit. Gonzalo Sanchius de Siles. El bachiller Viscaya.

\section{BIBLIOGRAFÍA}

Ayllón Gutiérrez, C. 2002. "Sobre las parroquias de la tierra de Alcaraz a finales de la Edad Media”, Cultural Albacete 12-13: 27-33.

Ayllón Gutiérrez, C. 2008. "Iglesia y poder en el marquesado de Villena. Los orígenes de la colegiata de Belmonte". Hispania Sacra 60 (121): 95-130.

Ayllón Gutiérrez, C. 2009. "Los Soriano: otro linaje eclesiástico en el cabildo de Cartagena”, Murgetana 120: 95-110.

Ayllón Gutiérrez, C. 2010. "Las iniciativas religiosas de don Juan Manuel en el señorío de Villena", en Homenaje al profesor Eloy Benito Ruano. I: 107-118. Murcia: Sociedad Española de Estudios Medievales.

Ayllón Gutiérrez, C. 2013. "El arcedianazgo de Alcaraz en sus orígenes", en Alcaraz. Del Islam al concejo castellano: 143-168. Albacete: Instituto de Estudios Albacetenses-Ayuntamiento de Alcaraz.

Azcona, T. de 1980. "Reforma del episcopado y del clero de España en tiempo de los Reyes Católicos y de Carlos V", en R. GarcíaVilloslada (Dir.), Historia de la Iglesia en España, III-1: 115-182. Madrid: Biblioteca de Autores Cristianos.

Diago Hernando, M. 1997. "El cabildo de clérigos de Ágreda a comienzos de la Edad Moderna", Celtiberia 91: 43-68. 
Díaz Ibáñez, J. 2003. Iglesia, sociedad y poder en Castilla. El obispado de Cuenca en la Edad Media. Cuenca: Alfonsípolis.

García Díaz, I. 1987. Agricultura, ganadería y bosque. La explotación económica de la tierra de Alcaraz (1475-1530). Albacete: Instituto de Estudios Albacetenses.

Guadalupe Beraza, M. L., 1972. Diezmos de la sede toledana y rentas de la mesa arzobispal (siglo XV), Salamanca: Universidad de Salamanca.

Guerreau, A. 2002. El futuro de un pasado. Barcelona: Crítica.

Herrera Mesa, P. 1978. "La universidad de clérigos de Córdoba en la baja Edad Media", Actas del I Congreso de Historia de Andalucía. Andalucía Medieval, II: 133-145. C.S.I.C.

Lasso de la Vega, M. 1945. El Señorío de Valverde. Cuenca:

Le Goff, J. 2003. En busca de la Edad Media. Barcelona: Paidós.

Marsilla de Pascual, F. 1989. "Aportación al estudio de las cofradías religiosas en la diócesis de Cartagena. Siglo XV", Mayurqa. Universitat de les Illes Balears. 22: 383-392.

Martín Martín, J. L. 2003. "El clero rural en la Corona de Castilla", en $\mathrm{M}^{\mathrm{a}}$ Desamparados Martínez San Pedro y Dolores Segura del Pino (ed.), La Iglesia en el mundo medieval y moderno. Almería: Instituto de Estudios Almerienses.

Martín Rodríguez, J. L. 1993. "Hermandades y ligas de clérigos en los reinos hispánicos". Cofradías, gremios y solidaridades en la Europa Medieval. XIX Semana de Estudios Medievales de Estella: 127-147.

Nieto Cumplido, M. 1991. Historia de la Iglesia en Córdoba. Reconquista y Restauración (1146-1326) (II). Córdoba: Cajasur.

Osorio Muñoz, M. 1984. "El bajo clero en Jaén en el tránsito a la Edad Moderna. La universidad de curas párrocos", La sociedad medieval andaluza: grupos no privilegiados. Actas del III Coloquio de Historia Medieval de Andalucía: 457-468. 
CABILDOS DE CLÉRIGOS EN LA BAJA EDAD MEDIA. LOS CASOS 55

DE ALCARAZ (ALBACETE) Y TRESJUNCOS (CUENCA)

Perez de Pareja, E. 1740. Historia de la primera fundación de Alcaraz y milagroso aparecimiento de $N$. $S^{a}$ de Cortes. Valencia: Imp. Joseph Thomas Lucas (Ed. facsímil 1997. José Sánchez Ferrer. Albacete: Instituto de Estudios Albacetenses).

Pretel Marín, A. 2010. "La Plaza de Alcaraz y la carrera artística de Andrés de Vandelvira", Homenaje a Alfonso Santamaría Conde. Albacete: Instituto de Estudios Albacetenses: 447-476.

Sánchez Herrero, J. 1990. "La Iglesia y la religiosidad andaluza durante los siglos XIII al XV", XX siglos 3-4: 405-456.

Vincent, C. 1993. "Les confréries de bas clercs, un expédient pour la réforme des séculiers? L'exemple du Mans", Le clerc séculier au Moyen Âge. Paris: Editions de La Sorbonne : 263-274. 